\title{
Joining of ultra-high-strength steels using resistance element welding on conventional resistance spot welding guns
}

\author{
Heinrich Günter ${ }^{1}(\mathbb{D}) \cdot$ Gerson Meschut ${ }^{1}$
}

Received: 8 September 2020 / Accepted: 31 March 2021 / Published online: 15 April 2021

(C) The Author(s) 2021

\begin{abstract}
Single-step joining of dissimilar material combinations between ultra-high-strength steels and high-strength aluminium alloys with sufficient mechanical joint properties by using conventional resistance spot welding equipment has not been reported yet. In this research paper, a novel single-step joining technology, so-called self-penetrating resistance element welding, is introduced. First, the motivation for this novel joining technology, the state of the art in joining, and the process characteristics are presented. In the results section, the welding rivet geometry is first determined using forming simulations and validated by head tensile tests. Followed by the description of the welding process and its characteristics, the mechanical joint properties are reported. The results show that a numerically optimised welding rivet geometry can guarantee sufficient joint strength. By this welding rivet geometry, a thermally assisted penetration of aluminium and therefore welding to steel is possible with and without adhesive. Furthermore, it is shown that the welding process can be designed by means of simulations. Finally, the shear tensile tests prove that an overall sufficient joint strength is ensured.
\end{abstract}

Keywords Multi-material design · Ultra high-strength steel $\cdot$ High-strength aluminium $\cdot$ Resistance element welding $\cdot$ Joining process simulation

\section{Introduction}

In order to meet the legal requirements [1] for pollutant emissions, most of the automotive manufacturers use lightweight design and materials to reduce the car body weight [2]. In body-in-white manufacturing, materials such as ultra-highstrength steels, high-strength aluminium alloys, and fibrereinforced plastics are suitable for this purpose [3]. The targeted mixing of these materials is referred to as multimaterial design. Joining of dissimilar materials by using thermal joining technologies (e.g. arc welding, laser welding, resistance spot welding) is highly challenging due to significant differences in the material-physical properties (e.g. melting points, thermal conductivities, electrical resistances) [4]. For

Recommended for publication by Commission III - Resistance Welding, Solid State Welding, and Allied Joining Process

Heinrich Günter

Heinrich.Guenter@1wf.upb.de

1 Laboratory for Material and Joining Technology (LWF), Paderborn University, Paderborn, Germany this reason, mechanical joining and adhesive bonding are widely applied for joining dissimilar materials in multimaterial design [4]. However, the use of mechanical and adhesive bonding requires additional investments (e.g. equipment investment, additional personnel, training), reducing the cost-effectiveness of multi-material design [5]. A possible solution is the reutilisation of the already existing joining equipment. By combining the mechanical (riveting) and thermal (welding) joining principles, a new joining technology called resistance element welding (REW) is created. REW enables the multi-material design in mass production since conventional resistance spot welding (RSW) equipment can be used. REW can be understood as a thermal-mechanical joining technology which combines the advantages of mechanical (form-fit) and thermal (metallic bond) joining principles and enables a boundary stretch of joining dissimilar material combinations. The two-step version of REW is investigated in several research papers and dissertations [6 - 13]. In this case, the welding rivet (steel) is punched into the lightweight construction material (aluminium/plastic) first, and in a second step, this welding rivet is welded to a steel sheet. In between these two steps, the aluminium or plastic must be transported to the steel structure. In [6], the two-step REW 
using a welding rivet with a countersunk head is developed. In [7], a two-step process is developed, in which the first step operates free of protruding. In [8], a two-step joining process using a welding rivet which gets formed during punching is developed. In [9], a semi-hollow welding rivet according to self-pierce riveting (SPR) is developed and welded to the steel sheet. In [10], a short-time $(\leq 20 \mathrm{~ms})$ welding process is investigated. In [11], the shear tensile-properties are analysed. The joinability of magnesium to stainless steel and the joinability of aluminium to ultra-high-strength steel are studied in $[12,13]$, respectively. Since the idea of reducing the car body weight is old [14], the first application of multi-material design in mass production was implemented in the Ford Model T (comparing Ford Model T from 1915 to Ford Model T from 1925) [15]. In series production of the Audi A8 D2 (1994-2002), the Audi Space Frame (ASF) enabled a body in white made of aluminium [16]. In this case, mechanical (riveting, clinching, screwing, and hemming), adhesive bonding, and hybrid (riveting + adhesive bonding) joining technologies were used [17]. Adhesive bonding is widely used in body in white manufacturing due to its flexibility in joining similar and dissimilar materials, its low requirements for accessibility, and its simple process sequence [18]. Otherwise, significant disadvantages remain in surface pre-treatment, adhesive curing, non-destructive testing, and strength under peel tensile load [18, 19]. Mechanical joining technologies, e.g. clinching or SPR, are commonly used for joining materials with lower strength and higher ductility [20]. Clinching is a mechanical joining technology which enables form-locked joints without any additional auxiliary joining element. Conventional clinching is only suitable when the joined materials are relatively ductile, and the tensile/yield strength is low [16]. Press-hardened steels in dissimilar joints can only be joined by shear-clinching [21]. SPR is a mechanical joining technology for joining thicker aluminium sheets by using a semi-hollow rivet [16]. Both clinching and SPR provide a good material-thickness-flexibility and heatless process sequences [20]. However, these joining technologies have disadvantages in tool-set-frequency and relatively long process duration compared to RSW [22]. In the Ford F150 Gen. 13, an aluminium car body was implemented by mostly using mechanical joining technologies. Comparing the Ford F150 Gen. 12 (mostly steel, about 3000 spot welds, and no SPR) to the Ford F150 Gen. 13 (mostly aluminium, about 100 spot welds, about 2300 self-pierce rivets, and about 120 clinching joints) shows that RSW no longer plays a role in the Ford F150 Gen. 13 [15]. In general, mechanical and hybrid joining technologies are used when similar aluminium or dissimilar joints are manufactured [23]. On the other hand, RSW is most widely used for the joining of steel-based car bodies [24]. RSW therefore continues to play a dominant role in body-in-white production, and the vast majority of joining equipment is oriented towards RSW. For joining dissimilar material combinations (aluminium to steel), RSW is only suitable for fixing/bonding and does not work with additional adhesive [25]. Figure 1 shows the body in white of the Audi A6 C8 (left) beside exemplary joining tasks and the corresponding joinability by SPR and REW (right). All joints are either not or only restrictedly joinable by SPR. By the use of REW, these joints experience a significantly increased joinability.

Two-step REW was initially applied in mass production of car bodies within the Volkswagen Passat B8 [27]. In this research paper, the advanced version of two-step REW, socalled self-penetrating resistance element welding (SPREW), is presented and described in detail. Figure 2 shows the process sequence of SPREW, which can be divided into three subprocess steps. Within the first step, the sheets and the welding rivet are positioned between the electrode caps. A holding force is built up, which causes the welding rivet tip to partially penetrate the aluminium sheet. For a further penetration of the aluminium sheet, it is necessary to soften the aluminium by Joule heating. This process step is referred to as hot penetration $[16,28,29]$. Due to the current flow, the steel sheet and the welding rivet are heated up, and the aluminium sheet softens due to the heat absorption [30]. The thermally induced softening of the aluminium enables a full penetration of the aluminium sheet. After hot penetration, the welding process starts by welding the welding rivet tip to the steel sheet. During the welding process, the molten nugget grows into the welding rivet shank, and a metallic bond between the welding rivet and the steel sheet is created [31].

\section{Experimental procedure}

\subsection{Welding rivet geometries}

Figure 3 shows the initial welding rivet geometry [16] (left), which is divided into a welding rivet head and a welding rivet shank (centre), and the numerically optimised welding rivet geometry (right).

\subsection{Welding equipment}

Figure 4 (left) shows the welding configuration consisting of a robot-mounted welding gun in $\mathrm{C}$-frame design (Nimak PowerGun 2-C) and a 1000-Hz MFDC current source (Harms + Wende Genius HWI) with a constant current control system. The electrode caps, which are water-cooled with a minimum flow rate of $41 / \mathrm{min}$, are mounted on shafts with a diameter of $16 \mathrm{~mm}$. In order to ensure a reproducible positioning of the welding rivet, a dedicated welding device is used. The device illustrated in Fig. 4 (right) is used for this purpose. The pneumatically driven device can be attached to the electrode shaft using a clamping lever. The welding rivet holder is attached to the pivot arm, which can be rotated. An inductive 


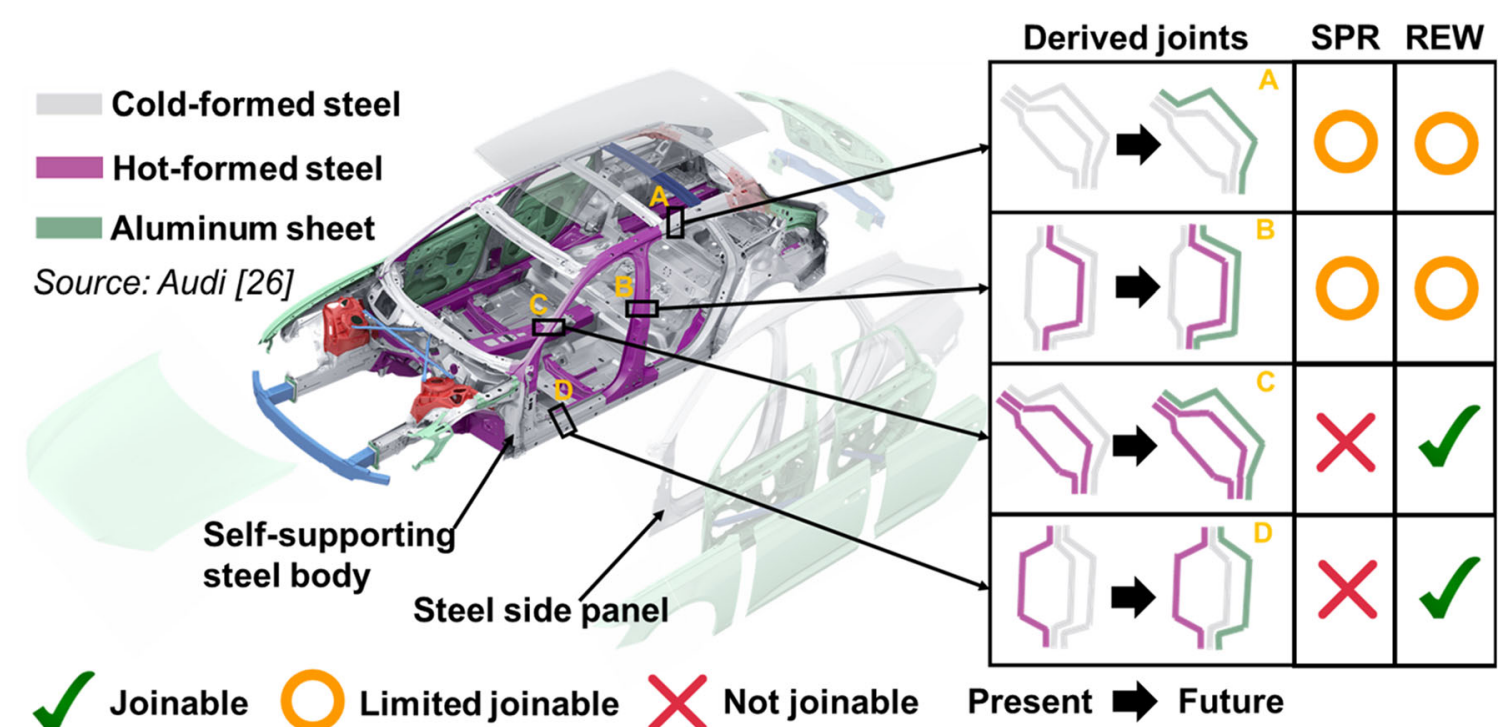

Fig. 1 Self-supporting steel body of the Audi A6 C8 utilising a side panel made of steel (left side) [26], and the joinability of selected joints by self-pierce riveting (SPR) and resistance element welding (REW) (right side)

sensor is attached to the pneumatic device, which triggers the pivot arm to move the welding rivet holder back to the initial position.

\section{Test materials}

Table 1 shows the chemical and mechanical properties of the test materials. The 6000 series aluminium alloy AlMg0.4Si1.2 (EN AW-6016) belongs to the group of heat-treatable wrought alloys. The aluminium is welded in the $\mathrm{T} 4$ condition and tested in the T66 condition by heating up the specimens to $180^{\circ} \mathrm{C}$ for $30 \mathrm{~min}$. This heat treatment simulates the dip-painting process [17]. The steel alloy $22 \mathrm{MnB} 5$ is a press-hardenable, boron-alloyed steel which is characterised by an ultra-high strength in heat-treated condition [32]. The steel alloy $20 \mathrm{MnB} 4$ is mainly used for auxiliary joining parts, such as screws and rivets, and has similar chemical, thermal, and electrical properties as the $22 \mathrm{MnB} 5$.

The used adhesive is a one-component, heat-curing, epoxybased adhesive especially developed for the body shop [33].
The adhesive is applied automatically on the aluminium sheet with a layer thickness of approx. $0.3 \mathrm{~mm}$ without pre-treatment. Table 2 shows the physical and mechanical properties of the adhesive.

\subsection{Simulation models}

Figure 5 shows the 2D axis symmetric forming simulation models for welding rivet design realised in Simufact ${ }^{\circledR}$ Forming 13 (Hexagon Corporate Services Ltd./MSC Software $\mathrm{GmbH}$ ). The left simulation model for shank design is used to determine the optimum tip angle $\left(\alpha_{\text {tip }}\right)$. Here, the punch is moved down towards the aluminium sheet and is fixed to the shank. The right simulation model for head design is needed to determine the optimum head height $\left(h_{\text {head }}\right)$. In contrast to the simulation model for shank design, here, a stiff tensile loading ring is fixed to the aluminium sheet. In order to simulate a head-tensile load case, the loading ring is moved upwards. In addition, the welding rivet is fixed to the steel sheet.

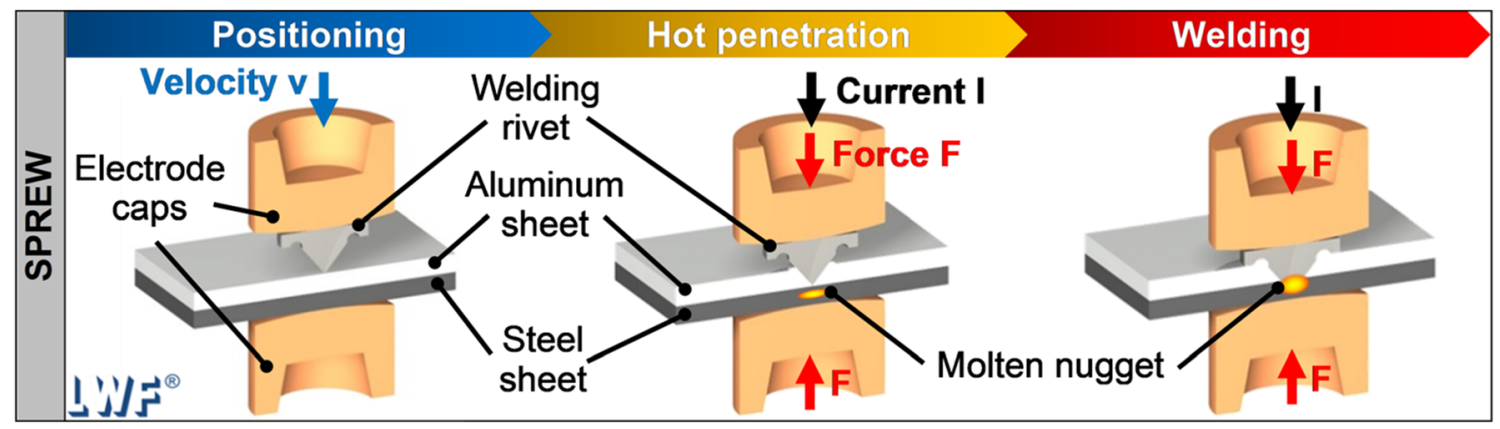

Fig. 2 Process sequence of self-penetrating resistance element welding (SPREW) 


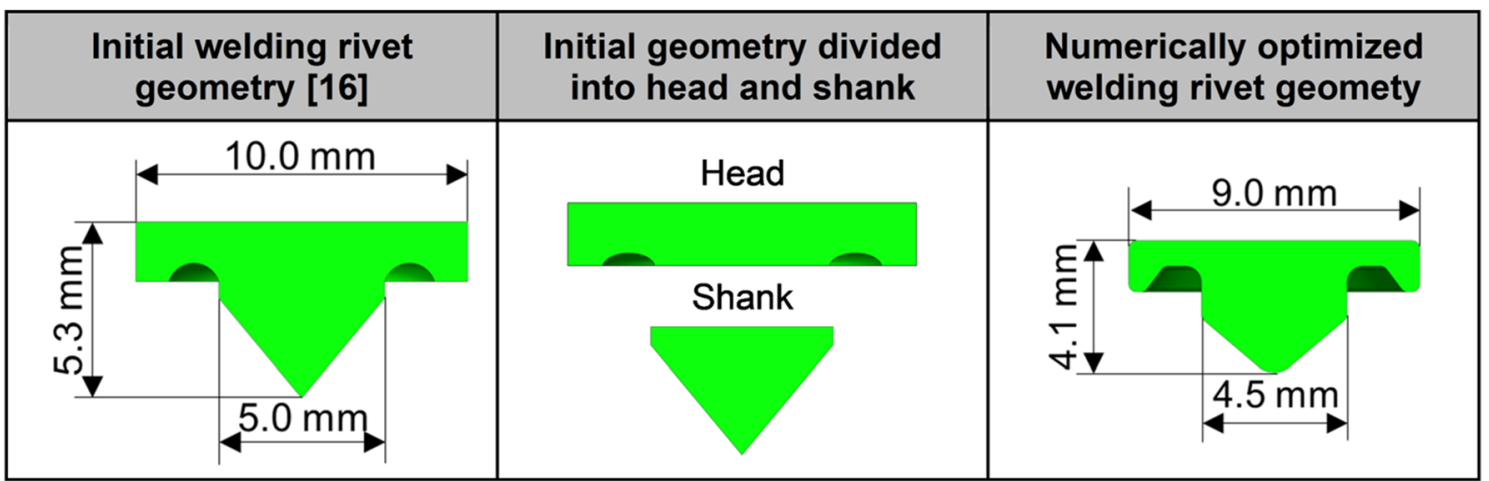

Fig. 3 Initial welding rivet geometry (left), subdivided in welding rivet head and shank (centre), and the numerically optimised welding rivet geometry (right)

Figure 6 shows the used 3D welding simulation models implemented in Sorpas ${ }^{2}$ 3D. The models are used to determine the temperature fields and the dynamic resistances during welding. In this case, only the welding process is simulated since hot penetration cannot be simulated within 3D due to missing damage criteria in the computational model. The simulation models consist of an upper electrode, an already inserted welding rivet, a pre-holed and formed aluminium sheet, one or two steel sheets, and a lower electrode. The electrode cap $(\mathrm{CuCr} 1 \mathrm{Zr})$ geometry F1-16-8.0-R50 corresponds to the geometry which is used in the experiments and is therefore water-cooled (see lower section in Fig. 6). Between each object, an interface is included. Three and four interfaces are included in the welding simulation model for two-sheet application and in the model for three-sheet application, respectively.

\section{Results}

\subsection{Welding rivet design}

In this section, the optimised welding rivet geometry (Fig. 3, right) is determined using forming simulations. Finally, this welding rivet geometry is verified using numerical and experimental head tensile tests. Figure 7 shows results of forming simulations for shank design. The diagram includes results of the minimum deformation energy $(\mathrm{W}=\mathrm{F} \cdot \Delta \mathrm{l})$, which is applied to move the punch towards the aluminium sheet to its final position $\left(\Delta \mathrm{l}_{\text {final }}\right)$ and simultaneously deform the shank. Furthermore, the diagram includes the minimum punching force, which is needed to move the shank to its final position. The diagram illustrates that the deformation energy is decreasing, while the tip angle $\left(\alpha_{\text {tip }}\right)$ is increasing. This circumstance

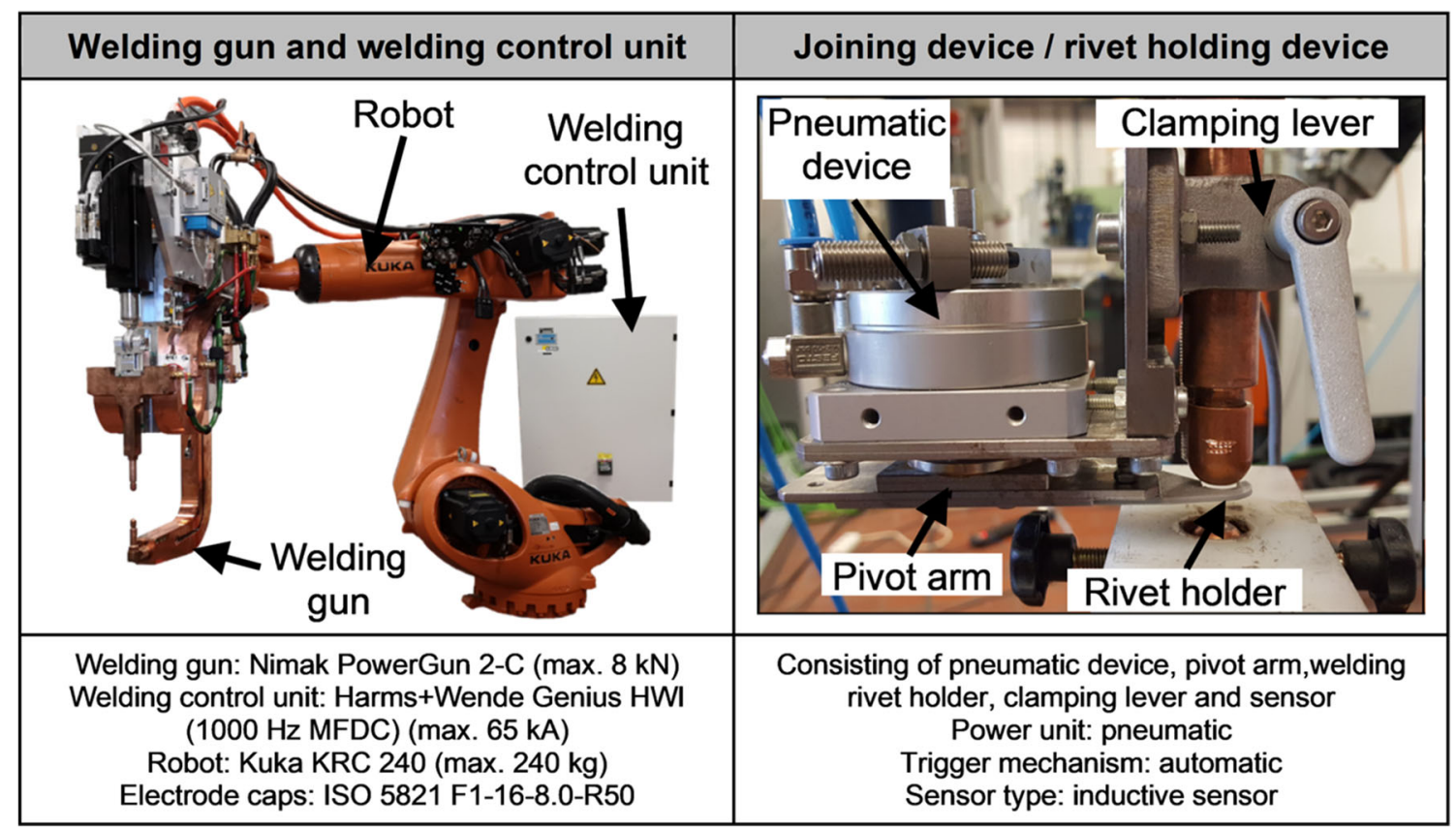

Fig. 4 Welding gun and control unit mounted on an industrial robot (left) and the pneumatic joining device developed especially for SPREW (right) 
Table 1 Chemical composition and mechanical properties of the investigated materials

\begin{tabular}{|c|c|c|c|c|c|c|c|c|c|c|c|c|c|c|}
\hline \multirow[t]{2}{*}{ Material } & \multicolumn{12}{|c|}{ Weight $[\%]$} & \multirow[t]{2}{*}{$\mathrm{R}_{\mathrm{m}}[\mathrm{MPa}]$} & \multirow[t]{2}{*}{$\mathrm{A}[\%]$} \\
\hline & $\mathrm{Al}$ & $\mathrm{B}$ & $\mathrm{C}$ & $\mathrm{Cr}$ & $\mathrm{Cu}$ & $\mathrm{Fe}$ & $\mathrm{Mg}$ & $\mathrm{Mn}$ & Mo & $\mathrm{Si}$ & $\mathrm{Ti}$ & $\mathrm{Zn}$ & & \\
\hline AlMg0.4Si1.2 T4 & 96.55 & - & - & 0.1 & 0.2 & 0.5 & 0.6 & 0.2 & - & 1.5 & 0.15 & 0.2 & 250 & 24 \\
\hline AlMg0.4Si1.2 T66 & & & & & & & & & & & & & 300 & 10 \\
\hline 22MnB5 PH & 0.05 & 0.1 & 0.25 & 0.2 & 0.1 & 97.6 & - & 1.5 & 0.1 & 0.3 & 0.05 & - & 1550 & 6 \\
\hline 20MnB4 & - & 0.05 & 0.23 & 0.3 & 0.25 & 97.67 & - & 1.2 & - & 0.3 & - & - & 520 & 14 \\
\hline
\end{tabular}

arises due to the condition of constant shank volume, and thus the total length of the shank decreases. The minimum punching force is increasing while the tip angle is also increasing. In this case, shanks with larger tip angles generate less cutting effect, which means that higher forces are necessary to penetrate the aluminium sheet. Due to the opposing curves, it can be assumed that the shank length reduction, resulting from the tip angle increase, has a greater effect on the energy absorption than on the minimum punching force. Looking at the corresponding images (centre), the aluminium sheet lifts while the tip angle increases. In this case, higher tip angles block the radial material flow during penetration, and therefore, the displaced material cannot move laterally, and a gap emerges between the aluminium and the steel sheet. This gap can lead to the kissing bond effect and should be kept as small as possible. Furthermore, Fig. 7 shows that a full displacement of the aluminium is not possible when a tip angle of $90^{\circ}$ is chosen, and therefore, the shank gets deformed unfavourably. The aim of this numerical shank design is to optimise the tip angle for an optimum penetration process with low forces, low deformation energy, and a small gap between the aluminium and the steel sheet. For this reason, a tip angle of $45^{\circ}$ should be chosen, which allows a full penetration of the aluminium with a small gap of $0.7 \mathrm{~mm}$, a low minimum punching force of 3.0 $\mathrm{kN}$, and a deformation energy of $16.3 \mathrm{~J}$.

Figure 8 shows the results of simulated head tensile tests for head design. The diagram includes the results of the deformation energy/energy absorption and the maximum force. At a head height ( $\mathrm{h}_{\text {head }}$ ) of up to $0.9 \mathrm{~mm}$, head failure occurs, which rapidly reduces the energy absorption and the force, wherefore a head failure must be avoided. At a head height between 1.1 and $1.5 \mathrm{~mm}$, the force increases due to the increasing head tensile stiffness. In parallel, the total displacement decreases, which results in less energy absorption. In this case, the head gets deformed, and the failure mode occurs in the aluminium sheet. Head deformation no longer occurs when the head height is greater than $1.5 \mathrm{~mm}$. The force decreases, the energy absorption stagnates, and the failure occurs exclusively in the aluminium sheet. Due to higher energy absorption, a head deformation is tolerated when the final failure occurs in the aluminium sheet. The optimum head height can be read from the diagram at $1.1 \mathrm{~mm}$. In this case, a force of approx. $2.9 \mathrm{kN}$ and an energy absorption of approx. $7.7 \mathrm{~J}$ can be achieved.

Figure 9 shows forming simulations which verify the numerically optimised welding rivet geometry. Compared to the initial welding rivet geometry, the head diameter is reduced from 10.0 to $9.0 \mathrm{~mm}$, and the shank diameter is reduced from 5.0 to $4.5 \mathrm{~mm}$, which results in a weight reduction from 1.24 to $0.81 \mathrm{~g}$. The volume of the ring groove under the rivet head is increased to $110 \%$ of the shank volume. The top simulation figure illustrates the welding rivet penetrating the aluminium sheet in cold state. Here, a tensile load is applied in the welding rivet head. In the figure below, the head is deformed due to the head tensile load, and finally, a failure occurs in the aluminium. The exemplary force-displacement curves show a good conformity between forming simulatio $\mathrm{n}$ (without previous applied head tensile load) and experiment. The resulting fracture pattern also illustrates a head deformation due to the head tensile load and the failure in the aluminium.

\subsection{Dynamic resistances and temperature fields}

In this section, the resulting dynamic resistances and temperature fields during welding are described. Figure 10 (left) shows the dynamic resistance curves from the experiments and simulations. The illustrated cross-sections (etched for $15 \mathrm{~s}$ in $3 \%$ alcoholic nitric acid $\mathrm{HNO}_{3}$ ) (centre) from the experiments are compared to the simulated ones. The welding parameters (current, electrode force, welding time) for the
Table 2 Physical and mechanical properties of the adhesive [33]

\begin{tabular}{lllllll}
\hline Colour & $\begin{array}{l}\text { Density } \\
{\left[\mathrm{kg} / \mathrm{m}^{3}\right]}\end{array}$ & $\begin{array}{l}\text { Viscosity } \\
{[\mathrm{Pas}]}\end{array}$ & $\begin{array}{l}\text { Stress at break } \\
{[\mathrm{MPa}]}\end{array}$ & $\begin{array}{l}\text { Strain at } \\
\text { break }[\%]\end{array}$ & $\begin{array}{l}\text { Lap shear } \\
\text { strength }[\mathrm{MPa}]\end{array}$ & $\begin{array}{l}\text { Peel strength } \\
{[\mathrm{MPa}]}\end{array}$ \\
\hline Red & 1230 & $\geq 30$ & 29 & 11 & $\geq 29$ & 11 \\
\hline
\end{tabular}




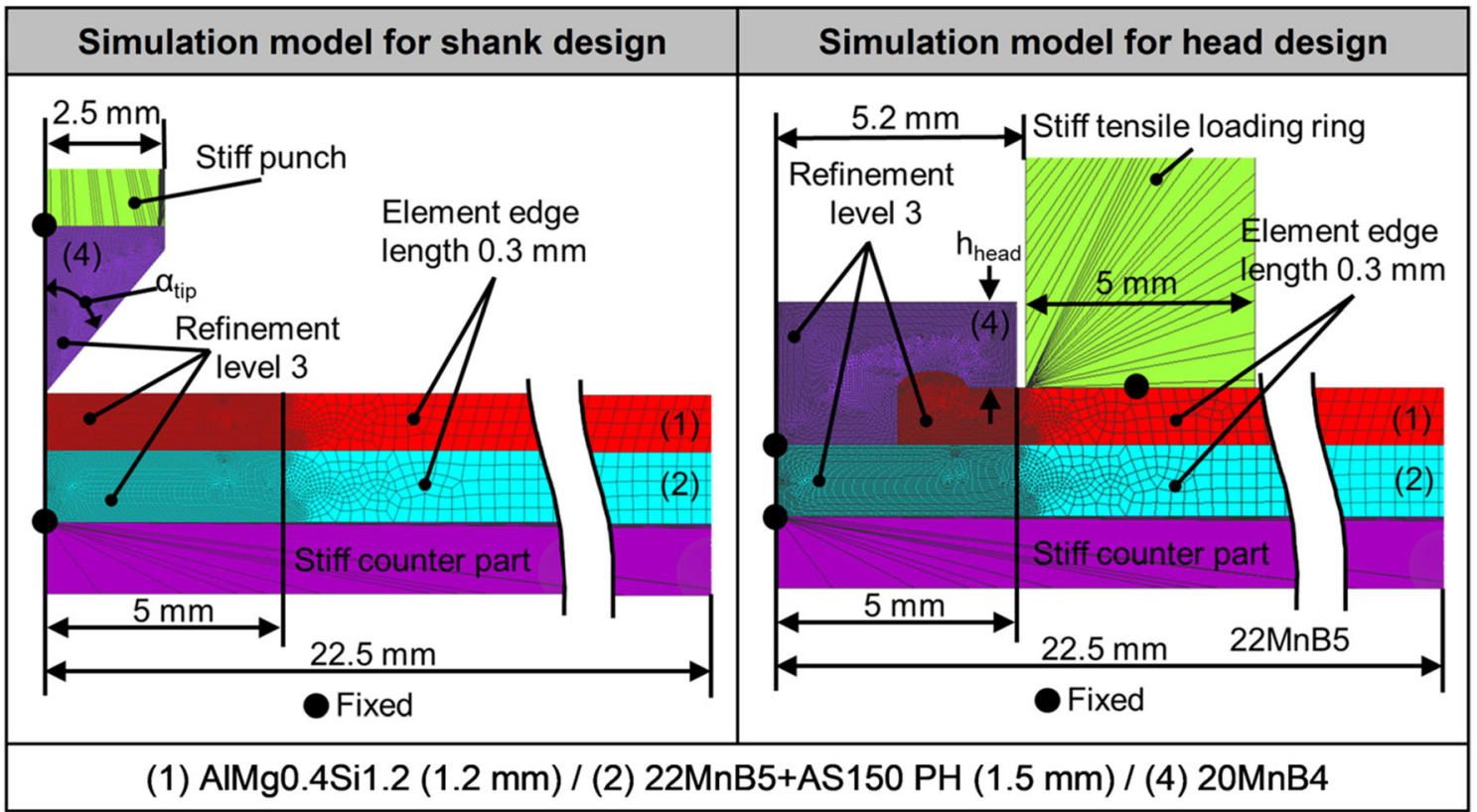

Fig. 5 Forming simulation model for shank design (left) and forming simulation model for head design (right), realised in Simufact ${ }^{\circ}$ Forming 13 (mechanical joining tool)

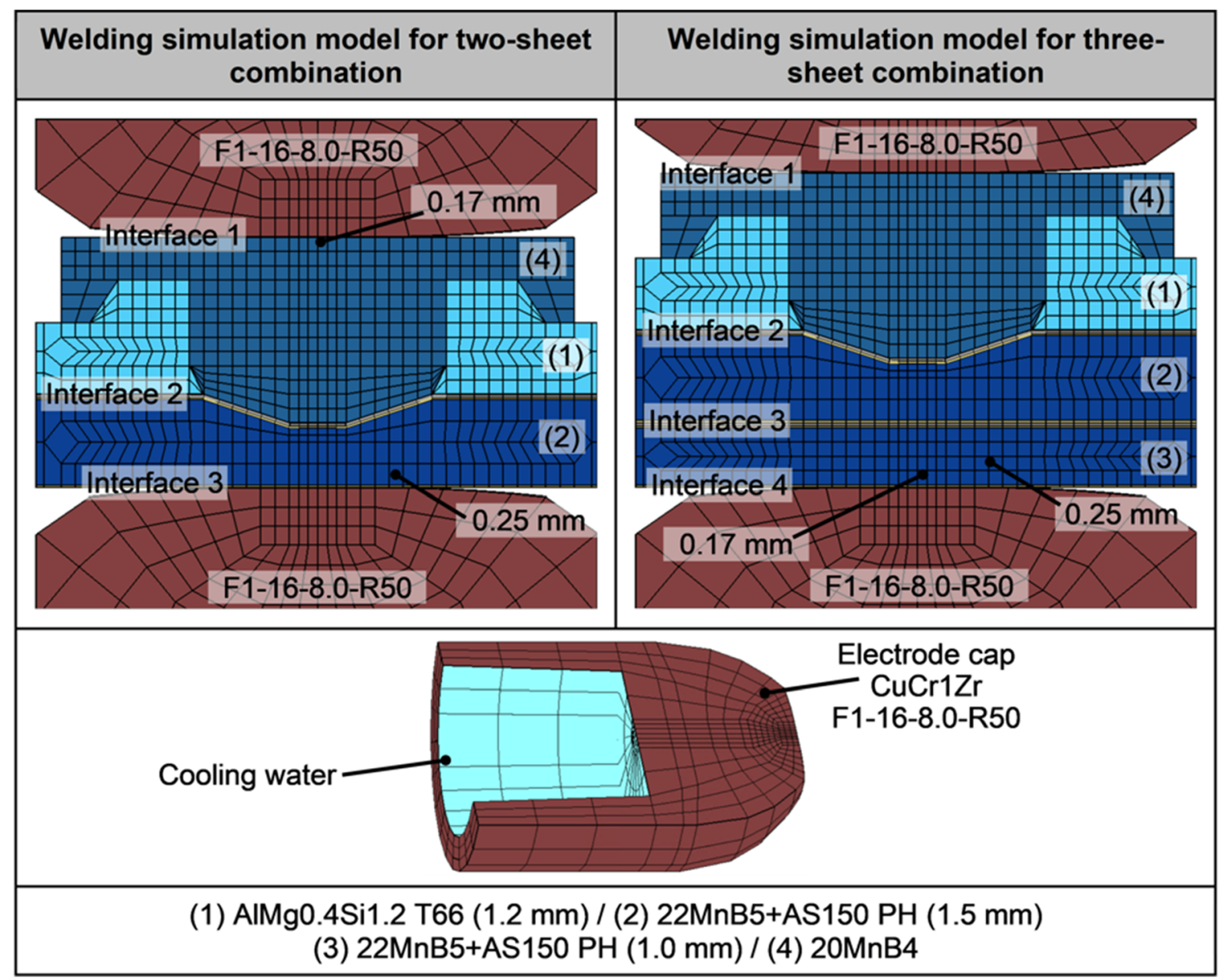

Fig. 6 Welding simulation model for two-sheet combination (upper left) and welding simulation model for three-sheet combination (upper right), realised in Sorpas ${ }^{(3 D}$ welding tool) 


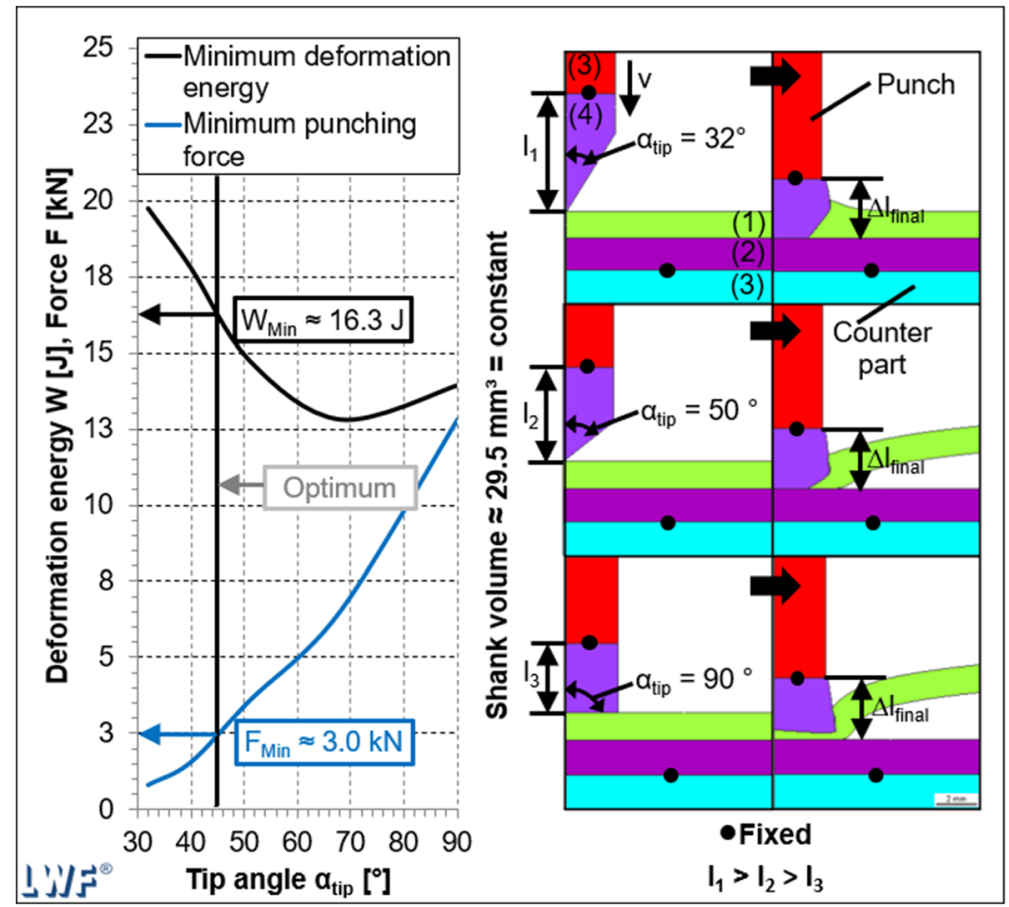

\begin{tabular}{|c|}
\hline Testing method \\
\hline Forming simulation for shank design \\
\hline Velocity v \\
$12.4 \mathrm{~mm} / \mathrm{s}$ \\
\hline Sheet material 1 \\
(1) AlMg0.4Si1.2 (1.2 mm) \\
\hline Sheet material 2 \\
\hline (2) 22MnB5 PH (1.5 mm) \\
\hline Sheet material 3 \\
\hline (3) Stiff punch / stiff counter part \\
\hline Welding rivet material \\
\hline (4) 20 MnB4 \\
\hline Element edge length \\
\hline 0.3 mm + Refinement level 3 \\
\hline Friction model \\
Coulomb + shear \\
\hline Friction coefficient $\boldsymbol{\mu} /$ factor $\mathrm{m}$ \\
$0.1 / 0.25$ \\
\hline Contact situation \\
\hline Node-to-segment contact \\
\hline Meshing model \\
\hline Advancing front quad \\
\hline Damage criteria \\
Splitting 0.01 mm \\
\hline
\end{tabular}

Fig. 7 Results of forming simulations for shank design including an analysis of relevant magnitudes (left), some figures of simulation results (centre), and relevant test information (right)

welding simulation were selected in accordance with the experiments. In these cases, only a single current pulse without any up- or downslopes was selected to guarantee a simple process control. The dynamic resistance curves from the experiments are divided into hot penetration and welding (according to Fig. 2). The simulated dynamic resistance curves (shown in Fig. 10, left) are not divided into these subsequences since the welding rivet is already located in its final position. Between 200 and $260 \mathrm{~ms}$, a drop in the dynamic resistance curves (experiments and simulations) can be

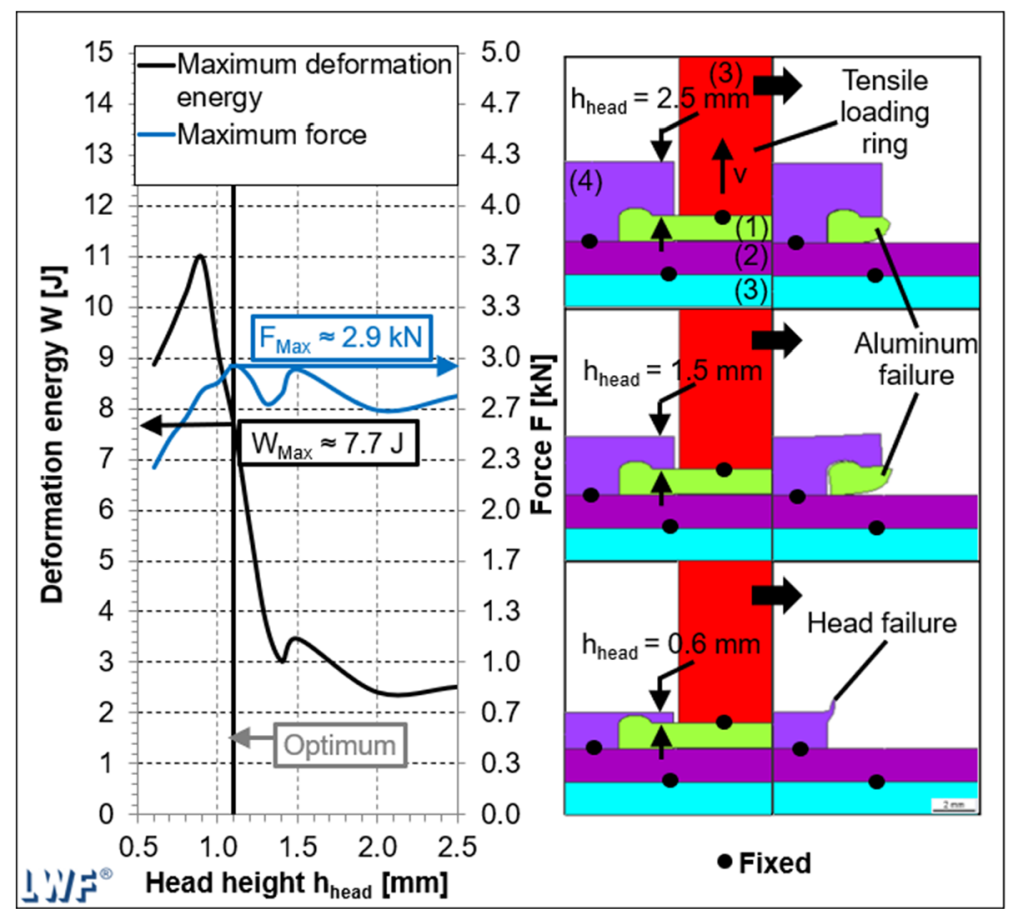

\begin{tabular}{|c|}
\hline Testing method \\
\hline Forming simulation for head design \\
\hline Velocity $\mathbf{~}$ \\
$0.16 \mathrm{~mm} / \mathrm{s}$ \\
\hline Sheet material 1 \\
\hline (1) AlMg0.4Si1.2 (1.2 mm) \\
\hline Sheet material 2 \\
\hline (2) 22 MnB5 PH (1.5 mm) \\
\hline Sheet material 3 \\
\hline (3) Stiff ring / stiff counter part \\
\hline Welding rivet material \\
\hline (4) 20 MnB4 \\
\hline Element edge length \\
\hline 0.3 mm + Refinement level 3 \\
\hline Friction model \\
\hline Coulomb + shear \\
\hline Friction coefficient $\boldsymbol{\mu} /$ factor $\mathrm{m}$ \\
$0.1 / 0.25$ \\
\hline Contact situation \\
\hline Node-to-segment contact \\
\hline Meshing model \\
\hline Advancing front quad \\
\hline Damage criteria \\
Splitting 0.01 mm \\
\hline
\end{tabular}

Fig. 8 Results of forming simulations for head design including an analysis of relevant magnitudes (left), simulation results (centre), and relevant test information (right) 

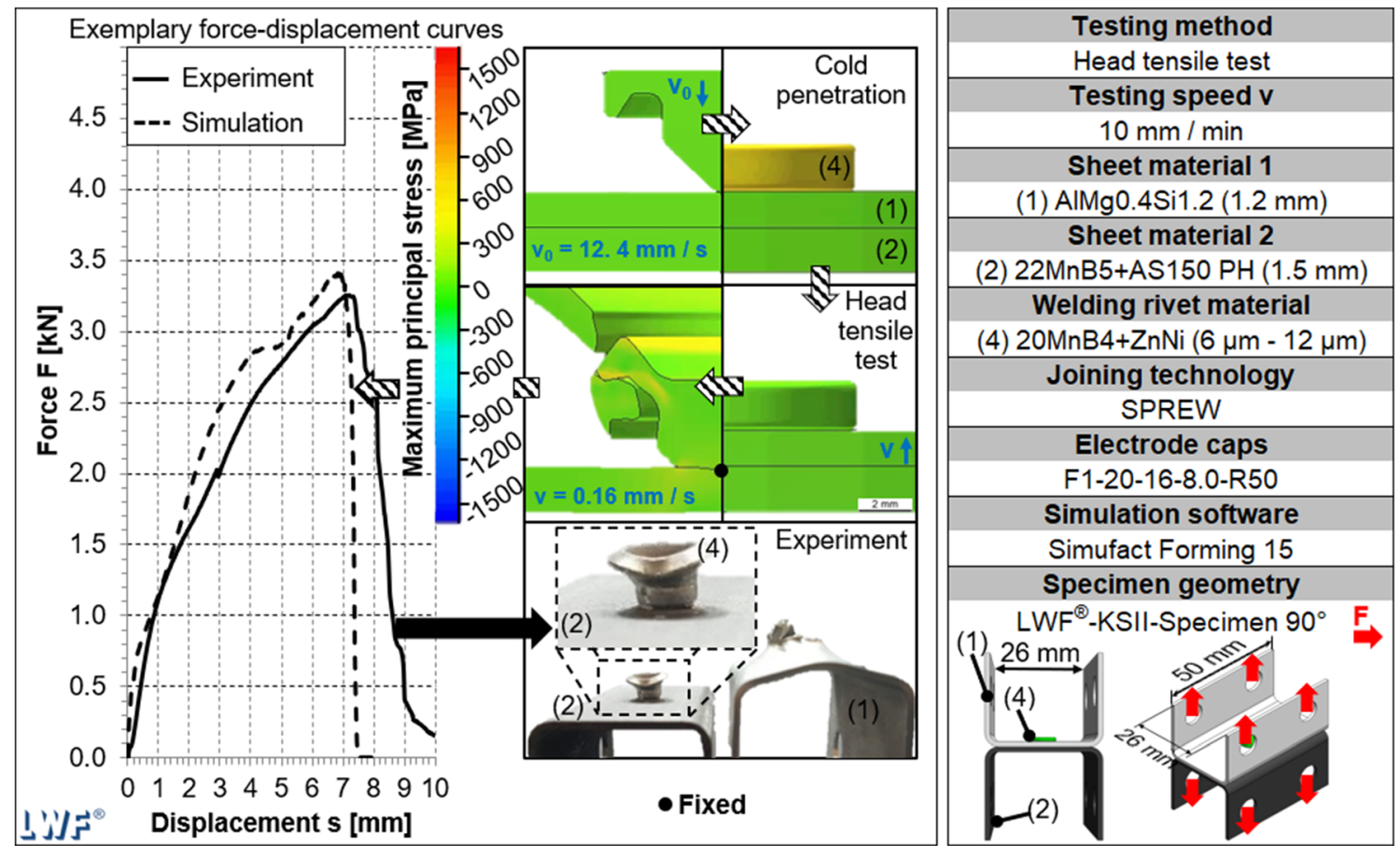

Fig. 9 Results of forming simulations including force-displacement-curves (left), simulation results (centre), and relevant test information (right)

detected. The reason for this drop is the reduction in contact resistances. In the experimental resistance curves of SPREW, there is a short increase from 260 to $300 \mathrm{~ms}$. The arrangement and shape of the electrodes concentrate the current flow in the steel sheet. This creates a molten zone in the steel first, increasing the resistance. At $300 \mathrm{~ms}$, the welding rivet head touches the aluminium sheet, a shunt occurs due to lower material resistance of aluminium, and the dynamic resistance curve drops again. The final position of the welding rivet is reached at $340 \mathrm{~ms}$. Now, the molten nugget expands from the steel sheet into the welding rivet. The simulated dynamic resistances increase between 260 and $350 \mathrm{~ms}$ because the weld nugget is created, and it expands from the steel sheet into the welding rivet. Due to the missing hot penetration in
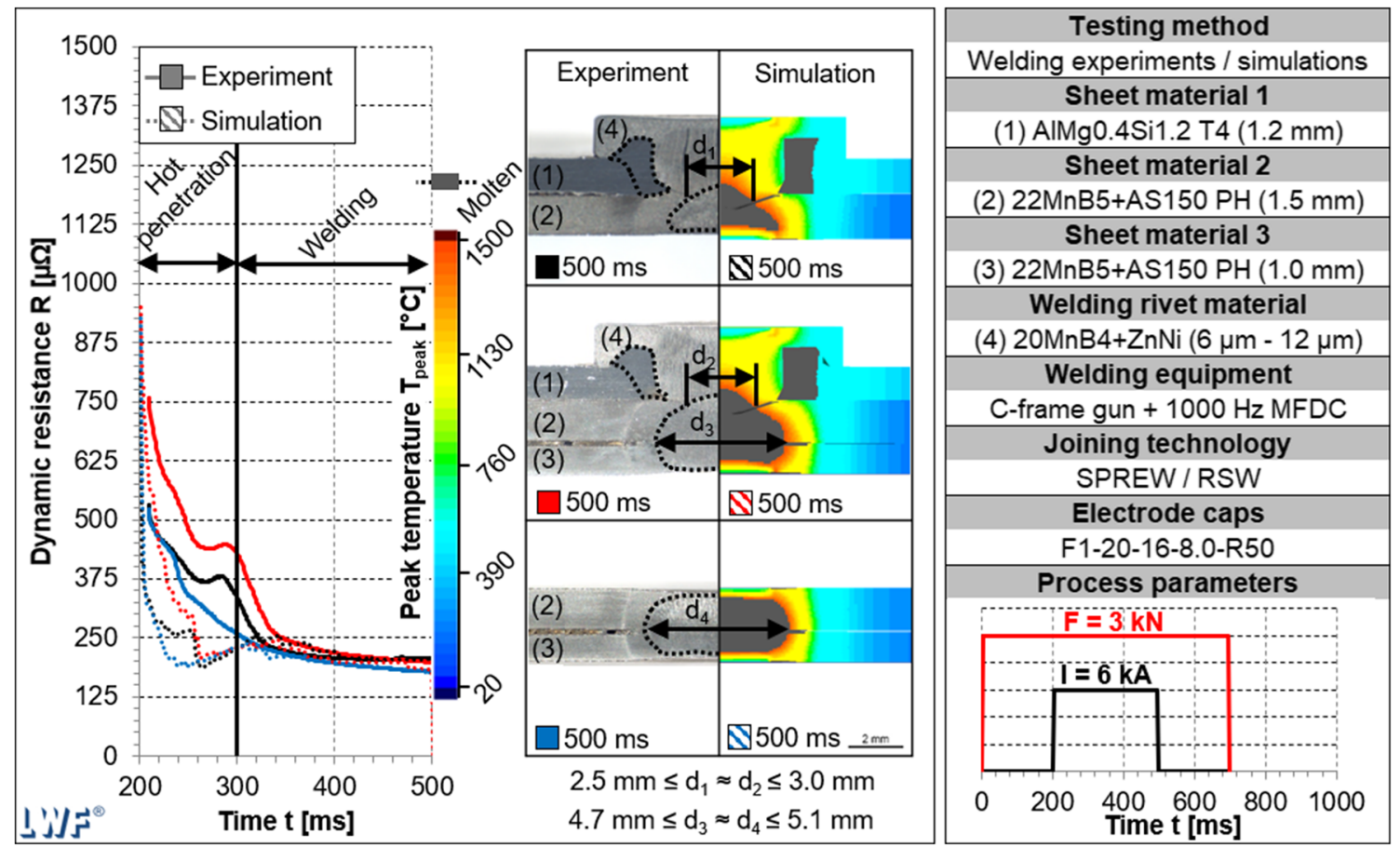

Fig. 10 Experimental and simulated dynamic resistances (left), cross-sections and simulation results (centre), and relevant test information (right) 
simulation, the simulated dynamic resistance curves differ from the experimental ones by up to $320 \mathrm{~ms}$. However, the shape is very similar, and at $320 \mathrm{~ms}$, the experimental and simulated dynamic resistance curves are superimposed. The comparison of experimental and simulated cross-sections illustrates that the molten zones in steel and aluminium only show minor deviations. For this reason, it can be assumed that the temperature fields in the experiments correspond to the simulated ones.

\subsection{Metallurgical joint properties and chemical composition}

In this section, the metallurgical structure of the joint and the chemical composition within the welding nugget and outside the shank are described. Figure 11 shows a two-sheet joint which is welded with higher energy input. The cross-section contains two areas, A and B, which are examined with a scanning electron microscope (SEM) and are illustrated in detail below. The cross-section illustrates a high welding nugget penetration within the welding rivet and a greater molten area in the aluminium (compared to figure 10) due to the higher energy input. The higher energy input leads to pores (left side from shank) and a gas duct (lower right from shank) within the aluminium. Furthermore, the slight head penetration in the aluminium is also caused by the molten aluminium under the head. The figure from the SEM in area A shows slight imperfections (pores). Aluminium inclusions can be detected at the geometric notches, which define the nugget diameter. The figure from the SEM in area B shows a small gas duct. The SEM figure of area $\mathrm{B}$ illustrates that the ferrite $(\mathrm{Fe}=$ green), which is mainly included in steel sheet and welding rivet, and the aluminium $(\mathrm{Al}=$ red $)$ are sharply separated from each other. Only a very thin layer, which arises from aluminium oxides (AlSi-coating), is visible between the welding rivet and the steel sheet. This thin layer defines the geometrical notch (areas A and B) since in this area, a full weld cannot be expected. However, this layer is much thinner than the AlSicoating and therefore cannot be replaced during hot penetration and welding.

Table 3 lists the points $\boldsymbol{\bullet} 1$ to $\cdot 6$ from the SEM figures A and $\mathrm{B}$ in Fig. 11. The table contains the weight and the atomic percentages of aluminium $(\mathrm{Al})$, iron $(\mathrm{Fe})$, and silicon $(\mathrm{Si})$. Other elements are also detected, but for the sake of a clear arrangement, they are not illustrated in this table. Point 4 in the SEM figure $A$ is furthermost from the virtual separating line and illustrates the lowest Al-content within the welding nugget at $0.11 \%$ (compared to table $1, \mathrm{Al}=0 \%$ to $0.05 \%$ ). Points $\cdot 1$ and $\cdot 3$ are the closest to the virtual separating line and include the highest Al-content of $0.21 \%$ and $0.24 \%$, respectively. It can therefore be assumed that small proportions of Al-atoms diffuse into the steel due to the proximity to the notch. Above the virtual separating line at point $\mathbf{5}$, the $\mathrm{Fe}$ content is the lowest at $94.2 \%$. The reason for this low $\mathrm{Fe}$ content in this area is a relatively high carbon (2.64 weight- $\%$, 10.78 atom. $-\%$ ) and a relatively high oxygen (1.30 weight- $\%$, 4.00 atom.- $\%$ ) content. These high contents occur due to carburisation during press-hardening [34]. In figure B, points .5 and -6 include Al-contents of $0.16 \%$ and $0.22 \%$, respectively. Point $\mathbf{- 3}$ shows proportions of $\mathrm{Al} 6.2 \%$, Si $2.19 \%$, and $\mathrm{Fe} 89.02 \%$. The proportions of $\mathrm{Al}$ and $\mathrm{Si}$ indicate that the AlSi-coating is diffused into the steel, compared to the
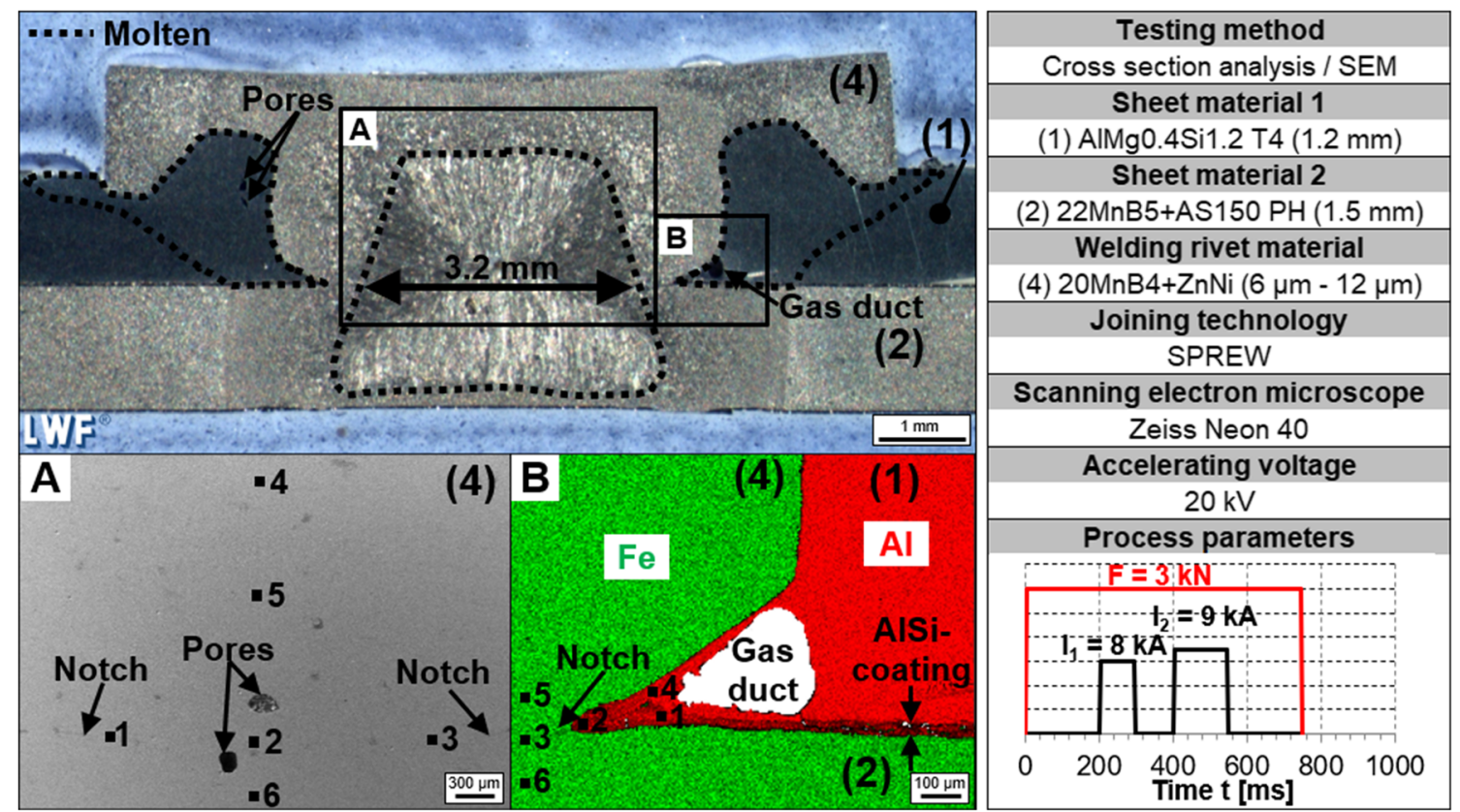

Fig. 11 Cross-section of SPREW joint (upper left), figures from the SEM within the weld (A) and outside the weld (B), and relevant test information (right) 
Table 3 Chemical composition inside the welding nugget (A) and outside the welding rivet shank (B), indicating the weight- and atomic-percentage

\begin{tabular}{|c|c|c|c|c|c|c|}
\hline & \multicolumn{6}{|c|}{ Energy dispersive X-ray spectroscopy [weight-\%/atom.-\%] } \\
\hline & \multicolumn{3}{|l|}{ A } & \multicolumn{3}{|l|}{$\mathrm{B}$} \\
\hline & Al-K & $\mathrm{Fe}-\mathrm{K}$ & $\mathrm{Si}-\mathrm{K}$ & Al-K & $\mathrm{Fe}-\mathrm{K}$ & $\mathrm{Si}-\mathrm{K}$ \\
\hline Point $\cdot 1$ & $0.24 / 0.47$ & $96.76 / 90.12$ & $0.25 / 0.46$ & $61.41 / 72.44$ & $34.35 / 19.58$ & $1.18 / 1.33$ \\
\hline Point $\mathbf{~} 2$ & $0.19 / 0.38$ & $97.02 / 92.69$ & $0.23 / 0.45$ & $47.31 / 57.30$ & $45.49 / 26.62$ & $0.79 / 0.92$ \\
\hline Point $\cdot 3$ & $0.21 / 0.41$ & $97.11 / 92.86$ & $0.38 / 0.72$ & $6.20 / 11.17$ & $89.02 / 77.48$ & $2.19 / 3.78$ \\
\hline Point $\cdot 4$ & $0.11 / 0.21$ & $96.86 / 91.06$ & $0.37 / 0.69$ & $96.90 / 96.45$ & $1.33 / 0.64$ & $-/-$ \\
\hline Point $=5$ & $0.19 / 0.35$ & $94.20 / 82.89$ & $0.55 / 0.96$ & $0.22 / 0.42$ & $96.70 / 89.89$ & $0.29 / 0.53$ \\
\hline Point $=6$ & $0.16 / 0.31$ & $96.27 / 89.74$ & $0.33 / 0.60$ & $0.16 / 0.31$ & $98.10 / 93.65$ & $0.33 / 0.62$ \\
\hline
\end{tabular}

interdiffusion layer in [35]. At point -4 , the Al-content is the highest at $96.9 \%$, and a low Fe content of $1.33 \%$ is visible. This suggests that some Fe atoms have diffused into the aluminium sheet. Points $\boldsymbol{\bullet} 1$ and $\mathbf{2}$ are located on the AlSi layer. Noticeably, the Si content is relatively low-with $1.18 \%$ and $0.79 \%$, respectively-compared to the initial content of approx. $10 \%$. This fact indicates a diffusion of Si into the aluminium sheet, but this is not proven here. Overall, it can be stated that the molten aluminium is completely displaced during hot penetration, and only the AlSi-coating gets dissolved within the welding nugget.

\subsection{Mechanical joint properties}

In this section, the results of shear-tensile tests according to DVS/EFB 3480-1 under quasi-static (10 mm/min) and crash load $(2 \mathrm{~m} / \mathrm{s})$ with two different overlapping lengths $(16 \mathrm{~mm}$ and $20 \mathrm{~mm}$ ) are presented. The quasi-static tensile specimens (free clamping length of $95 \mathrm{~mm}$ ) are tested on a static testing machine (Zwick100) by ZwickRoell, and the crash tensile specimens are tested on a crash testing machine (VHS 65/ $80-20)$ by Instron. All five specimens per material combination ( 5 specimens $\cdot 12$ material combinations $=60$ specimens $)$ are welded with the same process parameters, which are shown in Fig. $10(\mathrm{I}=6 \mathrm{kA}, \mathrm{t}=300 \mathrm{~ms}, \mathrm{~F}=3 \mathrm{kN})$. Figure 12 shows the results of quasi-static shear tensile tests (aluminium-steel joints) with an overlapping length of 20 $\mathrm{mm}$. The left section illustrates exemplary forcedisplacement curves for two- and three-sheet combinations with (hybrid) and without (elementary) adhesive as well as four cross-sections for the definition of the force application points. The middle section illustrates the maximum testing forces $\mathrm{F}_{\max }$ and the resulting energy absorption $\mathrm{W}_{\mathrm{b}}$ in a bar chart. The bars for elementary two- and three-sheet joints show maximum forces of $4.54 \mathrm{kN}$ and $4.74 \mathrm{kN}$, respectively. Furthermore, the bar chart illustrates that the energy absorption of the two-sheet joints $13.56 \mathrm{~J}$ is slightly lower compared to the three-sheet joints $14.90 \mathrm{~J}$. The bars for hybrid two- and three-sheet joints show that maximum forces of $13.03 \mathrm{kN}$ and
$12.86 \mathrm{kN}$ can be achieved and are therefore also similar. In terms of energy absorption, the trend is reversed compared to the elementary joints, whereupon the energy absorption of the three-sheet joints $29.97 \mathrm{~J}$ is less compared to the energy absorption of the two-sheet joints $34.40 \mathrm{~J}$. Overall, it can be stated that the two- and three-sheet joints have very similar values, and significant differences are not present.

Figure 13 shows the resulting fracture patterns of shear tensile tests for two- (left section) and three-sheet (right section) joints with (lower section) and without (upper section) adhesive. In this case, the elementary joints fail by bearing deformation of the aluminium sheet (10/10). The hybrid joints also fail by bearing deformation of the aluminium sheet (10/10).

Figure 14 shows the results of quasi-static and crash shear tensile tests (aluminium-steel joints) with a reduced overlapping length of $16 \mathrm{~mm}$. The bar chart illustrates that the elementary joints, which are tested under quasi-static load, can achieve a maximum force of $3.20 \mathrm{kN}$ and an energy absorption of $8.13 \mathrm{~J}$. The elementary joints, which are tested under crash load, can achieve a maximum force of $5.27 \mathrm{kN}$ and an energy absorption of $11.74 \mathrm{~J}$. Considering the hybrid joints, which are tested under quasi-static load, the maximum force increases to $11.79 \mathrm{kN}$, and the energy absorption increases to 21.64 J. The hybrid joints, which are tested under crash load, show that the maximum force increases to $13.82 \mathrm{kN}$, and the energy absorption increases to $150.93 \mathrm{~J}$. This increase can be described by the necking of the aluminium sheet.

Figure 15 shows the resulting fracture patterns of shear tensile specimens under quasi-static load (left section) and crash load (right section) with (lower section) and without (upper section) adhesive. The elementary joints fail by bearing deformation of the aluminium sheet (10/10). The hybrid joints also fail by bearing deformation of the aluminium sheet (10/ 10 ), and the necking of the aluminium sheet is visible (lower right).

Figure 16 shows the results of quasi-static shear tensile tests (steel-steel joints) with an overlapping length of 20 $\mathrm{mm}$. The bars for elementary two- and three-sheet joints show maximum forces of $15.73 \mathrm{kN}$ and $17.32 \mathrm{kN}$, respectively. 

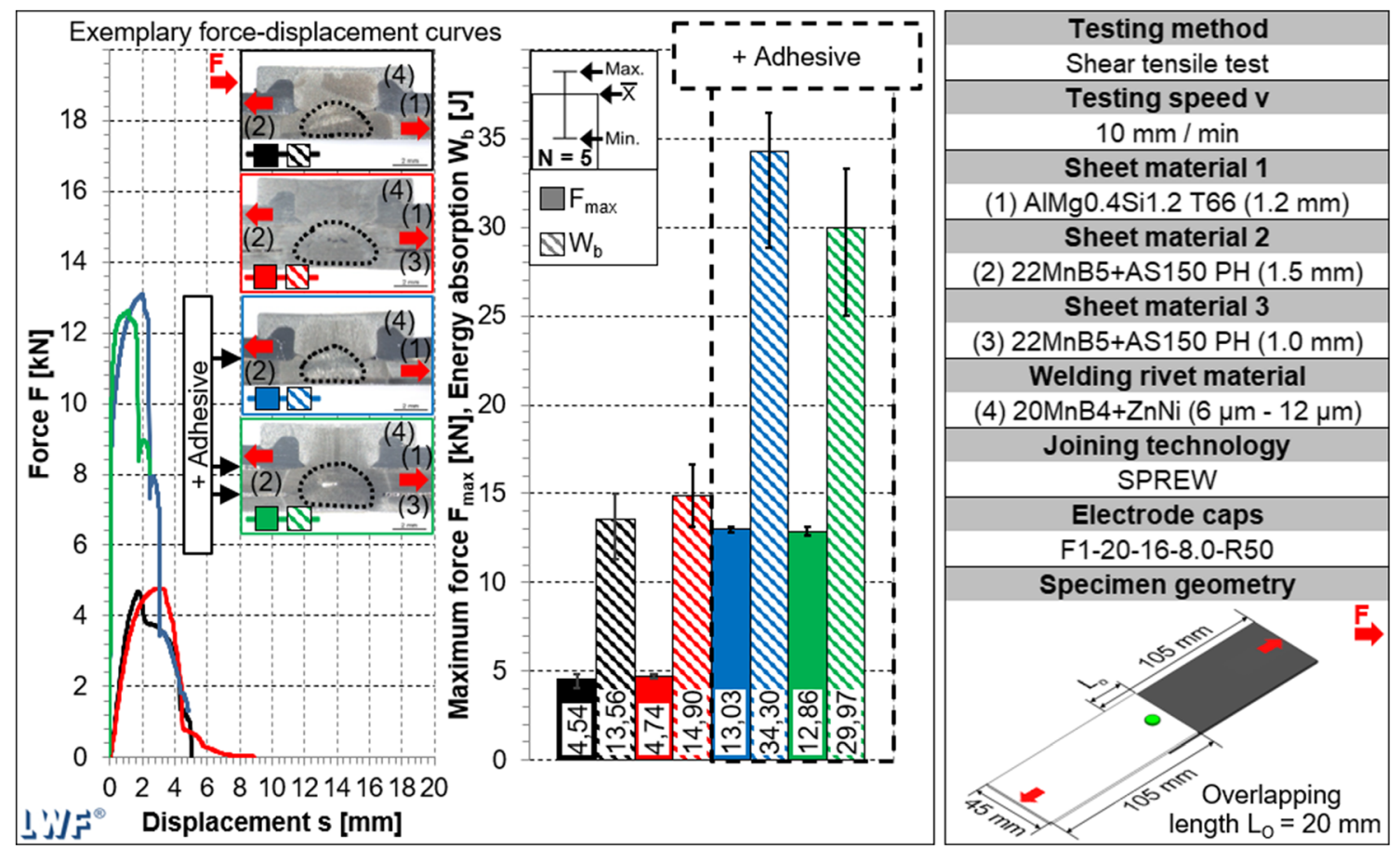

Fig. 12 Results of shear tensile tests for aluminium-steel joints (overlapping length $20 \mathrm{~mm}$ ) under quasi-static load including exemplary forcedisplacement curves for two- and three-sheet combinations with and

without adhesive (left), the achievable maximum forces and energy absorptions (centre), and relevant test information (right)

Furthermore, the bar chart illustrates that the energy absorption of the two-sheet joints $3.46 \mathrm{~J}$ is slightly lower compared to the three-sheet joints $4.27 \mathrm{~J}$. The bars for hybrid two- and

three-sheet joints show that maximum forces of $31.81 \mathrm{kN}$ and $34.07 \mathrm{kN}$ can be achieved. In terms of energy absorption, the trend is the same compared to the elementary joints,

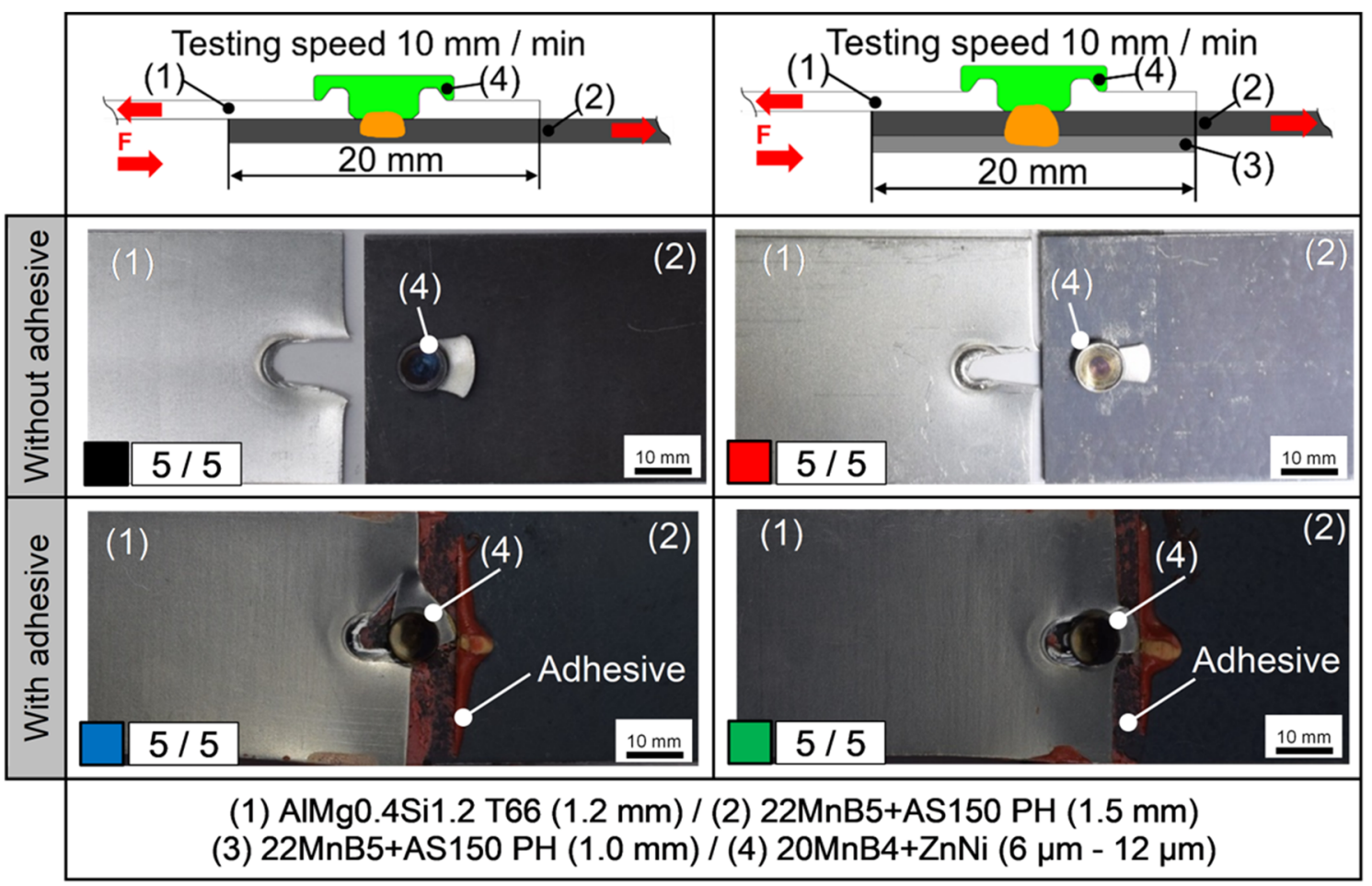

Fig. 13 Fracture patterns of aluminium-steel shear tensile specimens (overlapping length $20 \mathrm{~mm}$ ) tested under quasi-static load for two- (left section) and three-sheet (right section) combinations without (upper section) and with (lower section) adhesive 


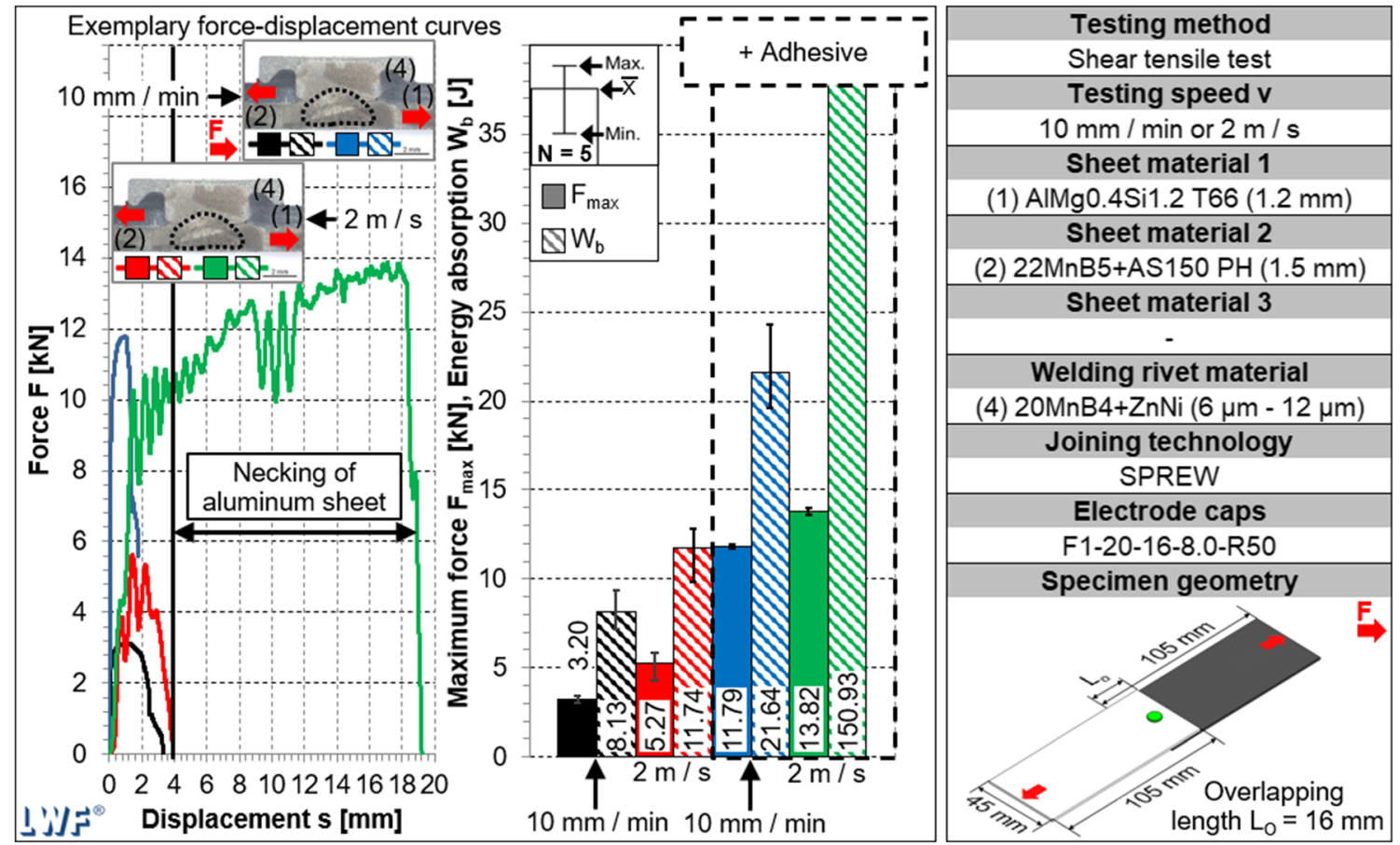

Fig. 14 Results of shear tensile tests (overlapping length $16 \mathrm{~mm}$ ) under quasi-static and crash load including exemplary force-displacement curves for two-sheet combinations with and without adhesive (left), the

whereupon the energy absorption of the two-sheet joints $5.05 \mathrm{~J}$ is less compared to the energy absorption of the threesheet joints $6.34 \mathrm{~J}$. Overall, it can be stated that the two- and three-sheet joints have very similar values, and significant achievable maximum forces and energy absorptions (centre), and relevant test information (right)

differences are not present. Furthermore, it can be concluded that adhesive leads to an increase of maximum force by approx. $100 \%$ and to an increase of energy absorption by approx. $47 \%$. Comparing the energy absorption of hybrid

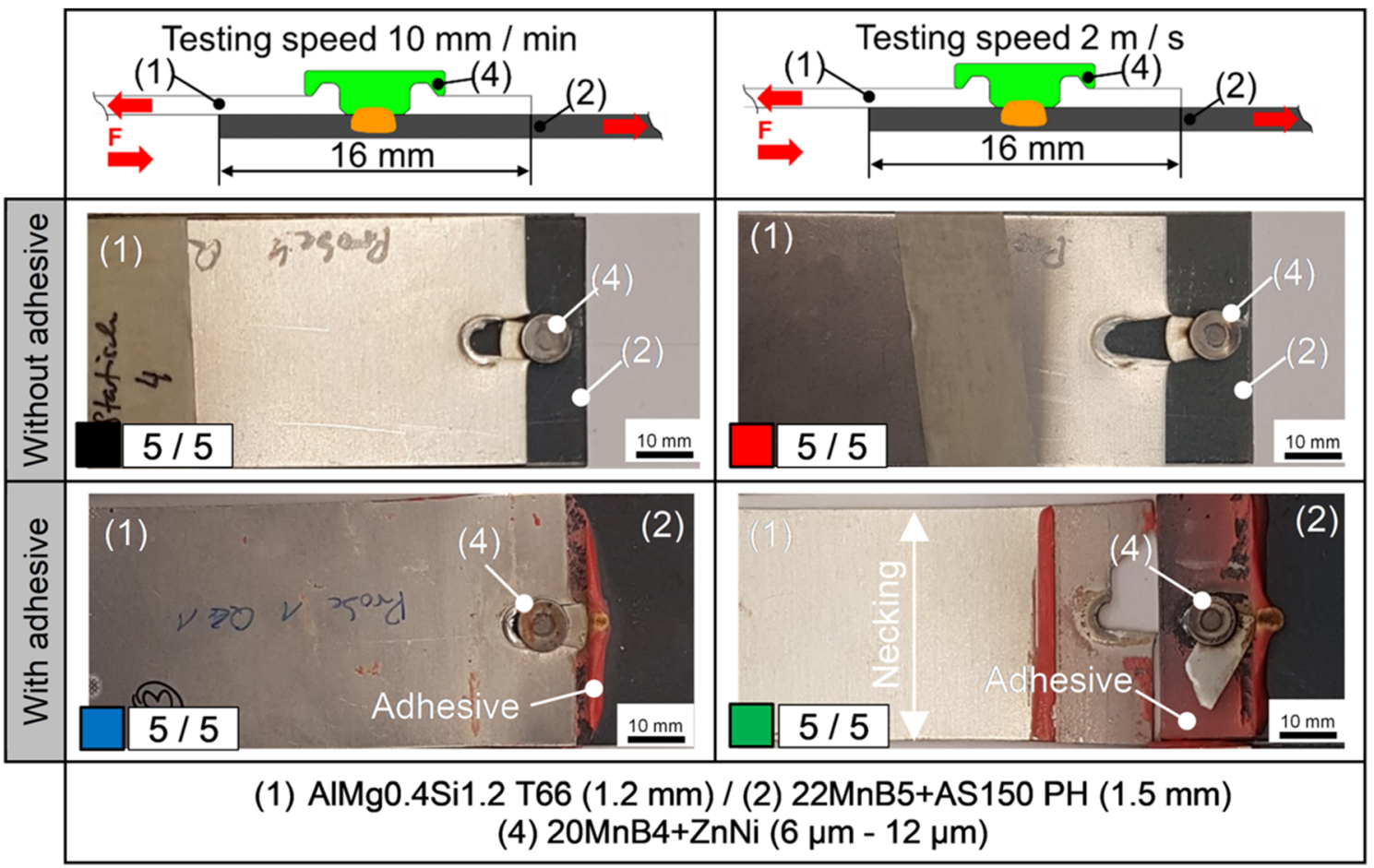

Fig. 15 Fracture patterns of aluminium-steel shear tensile specimens (overlapping length $16 \mathrm{~mm}$ ) tested under quasi-static (left section) and crash (right section) load for two-sheet combinations without (upper section) and with (lower section) adhesive 

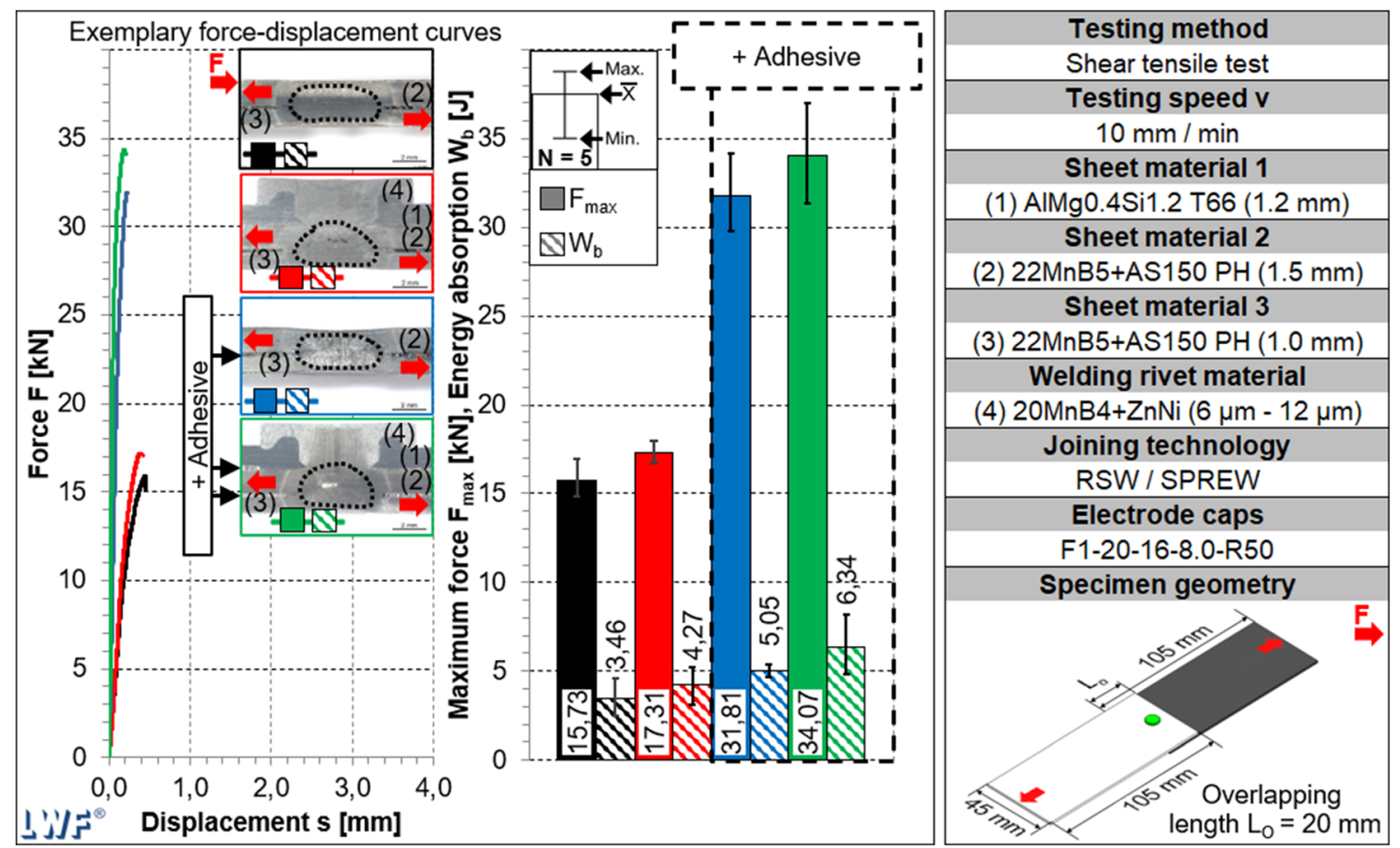

Fig. 16 Results of shear tensile tests for steel-steel joints (overlapping length $20 \mathrm{~mm}$ ) under quasi-static load including exemplary forcedisplacement curves for two- and three-sheet combinations with and

without adhesive (left), the achievable maximum forces and energy absorptions (centre), and relevant test information (right)

joints with the results from Fig. 12, it is obvious that adhesive does not improve the joint properties as much as it does when joining aluminium to steel.

Figure 17 shows the resulting fracture patterns of shear tensile tests for two- (left section) and three-sheet (right section) joints with (lower section) and without (upper section)

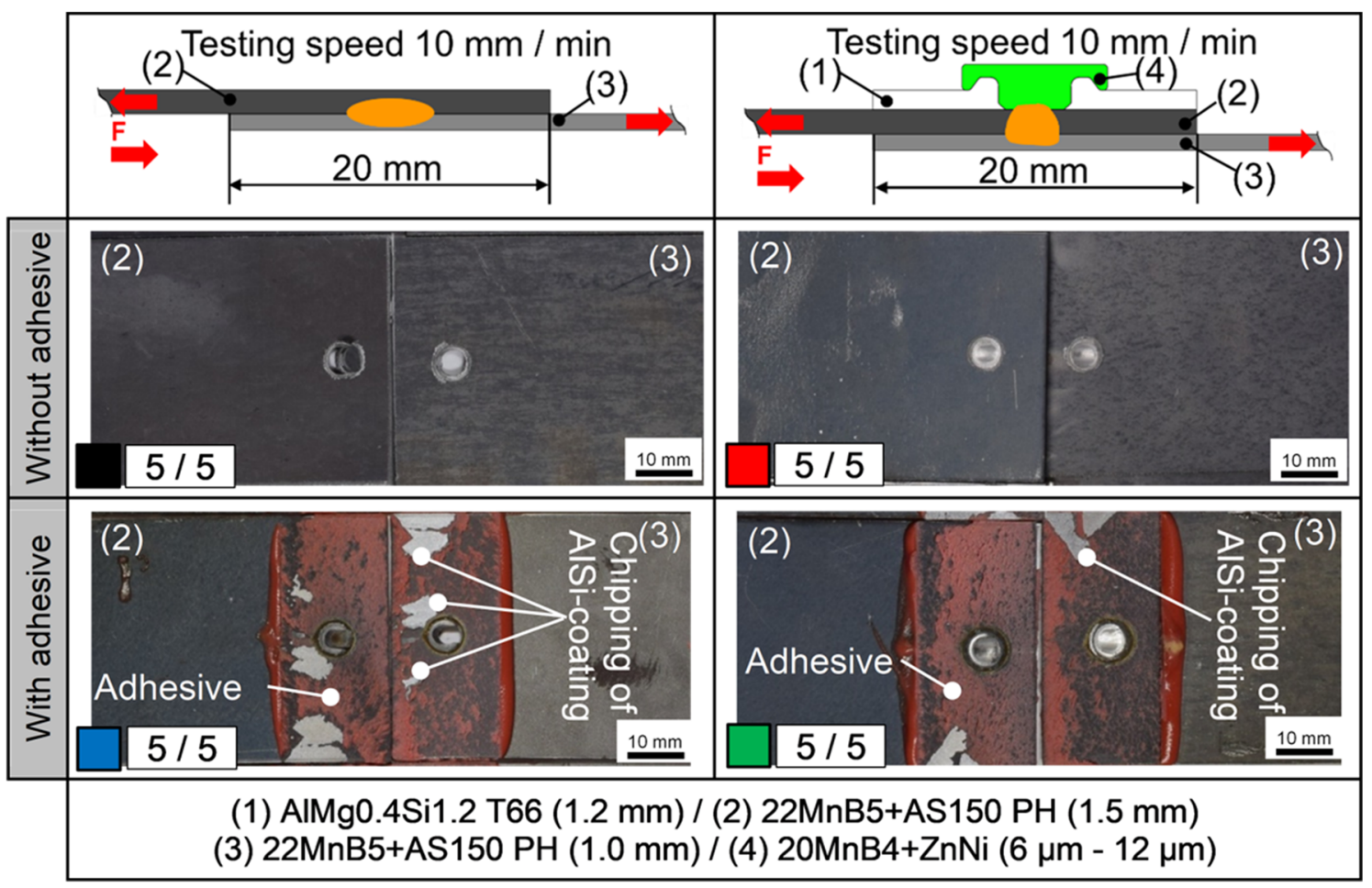

Fig. 17 Fracture patterns of steel-steel shear tensile specimens (overlapping length $20 \mathrm{~mm}$ ) tested under quasi-static load for two- (left section) and threesheet (right section) combinations without (upper section) and with (lower section) adhesive 
adhesive. Since the welding nugget diameter of approx. $4.9 \mathrm{~mm}$ is sufficiently dimensioned, the two-sheet joints fail by plug failure mode (10/10). The failure mode of the threesheet joints differs since a shear failure can always be detected $(10 / 10)$. It is likely that this effect is caused by the additional aluminium layer, thereby increasing the stiffness of the shear tensile specimen and permitting less peel load. Furthermore, the fracture patterns of hybrid joints show a chipping of the AlSi-coating on the steel surface (see Fig. 17 (lower section)). Overall, the adhesive joints fail by cohesion failure, and the nugget failure mode is acceptable. Finally, it can be assumed that the selected process parameters generate sufficient joint strengths, and the welding nugget diameters $d>4 \cdot \sqrt{ }\left(t_{\min }=\right.$ $1.0 \mathrm{~mm}$ ) are therefore sufficiently dimensioned.

\section{Discussion}

For the numerical welding rivet design in cold-state, an initial geometry was divided into a head and a shank for excluding mutual interactions. This subdivision allows an independent design of experiments (one factor at a time) and therefore a simplified evaluation. It could be shown that the tip angle has an influence on the material flow and a gap increase could be detected when tip angles larger than $40^{\circ}$ were used. The forming simulations for head design showed that the head height has an influence on the maximum head tensile force and the resulting energy absorption. When a head height less than $1.1 \mathrm{~mm}$ was used, the maximum force rapidly decreased. Therefore, head heights larger than $1.1 \mathrm{~mm}$ are recommended. The results of numerical and experimental head tensile tests showed a good accordance. Thus, this approach can be recommended for welding rivet design. Nevertheless, it should be considered that the heat input during hot penetration has an influence on shank deformation and metallurgical notches. Therefore, an experimental alignment should always be executed. The welding simulations, which were carried out to determine the temperature fields and dynamic resistances, also illustrated a good accordance to the experiments. However, the experimental resistances differed from the simulated ones due to missing hot penetration. The typical shunt, which is characterised by a dip in resistance curves due to contact between welding rivet head and aluminium sheet, was not represented in welding simulations. On the other hand, the resulting molten zones in aluminium and steel showed a good accordance. Thus, the used welding simulation models can be recommended for determining nugget diameters and molten zones. The metallurgical and chemical investigations proved that aluminium could be fully penetrated during hot penetration due to its molten state. Only small amounts of aluminium (Al) and silicon ( $\mathrm{Si}$ ) were detected within the welding nugget. However, these amounts can be explained by the diffusion of the AlSi-coating within the molten nugget. Finally, the shear tensile tests with different overlapping lengths and testing velocities reported that the welding nugget guarantees a higher joint strength than the form-fit since failure always occurs in the aluminium instead of the welding nugget (shear failure). The application of an adhesive layer could further improve the mechanical joint properties. Under crash-load, the adhesive could improve the energy absorption by approx. $1185 \%$. It is highly recommended to apply adhesive between aluminium and steel due to its joint improvement, electro-chemical separation, and electrical insulation. The application of an additional adhesive layer between steel sheets should be considered optional since the improvement in energy absorption by approx. $47 \%$ is relatively low. An improvement in the achievable maximum tensile shear forces by approx. $100 \%$ might potentially justify an additional process step. In summary, the results show that SPREW is very well suited for joining mixed joints in two- and three-sheet applications.

\section{Summary}

In this research paper, it was shown that REW represents a suitable solution to overcome the metallurgical incompatibility of dissimilar material compounds. In a large review [36], REW was compared to other welding technologies. In this review, REW was seen to provide a high joint quality. It thus represents a promising approach for manufacturing dissimilar joints in multi-material design. In this research paper, the advanced version of REW, so-called self-penetrating resistance element welding (SPREW), was introduced. First, the welding rivet geometry was determined using forming simulations. The welding process and its characteristics as well as the chemical composition of the resulting dissimilar joint were described. Finally, the mechanical joint properties were investigated using shear tensile tests with and without additional adhesive. The results showed that the simulations matched the experiments, and the aluminium is fully displaced during hot penetration. The shear tensile tests illustrated that the welding nugget between the welding rivet and the steel sheets enables sufficient joint strengths since failure always occurs in the aluminium. Furthermore, it was presented that a combination of one aluminium and two ultra-high-strength steel sheets could be joined by SPREW, which is not possible to accomplish within a single step by means of any other joining technology.

Acknowledgements In this research paper, selected results of the funded research projects IGF No. 19215 N (FOSTA P 1054) were presented. The 
IGF project IGF No. 19215 N (FOSTA P 1054) of the Research Association for Steel Application - FOSTA, Sohnstrasse 65, 40237 Düsseldorf was promoted through the AiF under the programme for the promotion of joint industrial research and development (IGF) by the Federal Ministry for Economic Affairs and Energy due to a resolution of the German Bundestag.

Funding Open Access funding enabled and organized by Projekt DEAL.

Open Access This article is licensed under a Creative Commons Attribution 4.0 International License, which permits use, sharing, adaptation, distribution and reproduction in any medium or format, as long as you give appropriate credit to the original author(s) and the source, provide a link to the Creative Commons licence, and indicate if changes were made. The images or other third party material in this article are included in the article's Creative Commons licence, unless indicated otherwise in a credit line to the material. If material is not included in the article's Creative Commons licence and your intended use is not permitted by statutory regulation or exceeds the permitted use, you will need to obtain permission directly from the copyright holder. To view a copy of this licence, visit http://creativecommons.org/licenses/by/4.0/.

\section{References}

1. European Union (2019) Regulation (EU) 2019/631 of the European Parliament and of the European Council of 17 April 2019 setting $\mathrm{CO}_{2}$ emission performance standards for new passenger cars and for new light commercial vehicles and repealing Regulations (EC) No 443/2009 and (EU) No 510/2011.

2. Federal Ministry for Economic Affairs and Energy (2021) Leichtbaustrategie für den Industriestandort Deutschland.

3. Meschke J, Tölle J, Berger L (2017) Multimaterialkonzept für ein Elektrofahrzeug. ATZ - Automobiltechnische Zeitschrift 119:4853. https://doi.org/10.1007/s35148-017-0127-4

4. Janzen V, Olfermann T, Hahn O, Meschut G (2014) Innovative joining technologies for multi-material structures. Welding in the World 58:65-75. https://doi.org/10.1007/s40194-013-0098-3

5. Janzen V, Günter H, Meschut G (2017) Joining process optimization of the resistance element welding for continually changing steel material properties. In: 5th International Conference on Steel in Cars and Trucks (SCT 2017), Amsterdam.

6. Meyer C ( $\left.\begin{array}{llll}2 & 0 & 1 & 6\end{array}\right)$ Weiterentwicklung des Widerstandselementschweißens für den Einsatz in der automobilen Serienfertigung. Dissertation, Paderborn University.

7. Hartwig-Biglau S (2016) Entwicklung eines impulsartig und butzenfrei eingetriebenen Elementes für das Widerstandsschweißen von Aluminium-Stahl-Verbindungen. Dissertation, Paderborn University.

8. Pietsch T (2020) Entwicklung des Prägeelementschweißens für Aluminium-Stahl Verbindungen im Karosseriebau. Dissertation, Paderborn University.

9. Kotschote C (2018) Widerstandspunktschweißen mit Stanzelement. Dissertation, Technical University of Ilmenau.

10. Holtschke N, Jüttner S (2017) Joining lightweight components by short-time resistance spot welding. Welding in the World 61:413421. https://doi.org/10.1007/s40194-016-0398-5

11. Meinhardt M, Endres M, Graf M, Lechner M, Merklein M (2019) Analysing resistance element welding with upset auxiliary joining steel-elements under shear load. Procedia Manufacturing 29:329336. https://doi.org/10.1016/j.promfg.2019.02.145

12. Manladan SM, Yusof F, Ramesh S, Zhang Y, Luo Z, Ling Z (2017) Microstructure and mechanical properties of resistance spot welded in welding-brazing mode and resistance element welded magnesium alloy/austenitic stainless-steel joints. Journal of Materials Processing Tech. 250:45-54. https://doi.org/10.1016/j.jmatprotec. 2017.07.006

13. Ling Z, Li Y, Luo Z, Feng Y, Wang Z (2016) Resistance element welding of 6061 aluminum alloy to uncoated $22 \mathrm{MnMoB}$ boron steel. Materials and Manufacturing Processes 31:2174-2180. https://doi.org/10.1080/10426914.2016.1151044

14. Lanzeratz H, Pasligh N (2013) Lightweight design with structural adhesives and foams. In: Joining Conference, Bad Nauheim.

15. Wesemann J (2016) Ford F150 - Leichtbau in der Großserie. In: Faszination hybrider Leichtbau, Wolfsburg.

16. Friedrich HE (2017) Leichtbau in der Fahrzeugtechnik. Wiesbaden, Germany. https://doi.org/10.1007/978-3-658-12295-9

17. Ostermann F (2007) Anwendungstechnologie Aluminium. Heidelberg, Germany. https://doi.org/10.1007/978-3-540-69451-9

18. Habenicht G (2009) Kleben - Grundlagen, Technologien, Anwendungen. Heidelberg, Germany. https://doi.org/10.1007/ 978-3-540-85266-7

19. Beck C, Goldmann F, Hahn O (2016) Belastungskollektive auf punktförmige Fügeverbindungen. Lightweight Design 9:32-37. https://doi.org/10.1007/s35725-016-0050-8

20. Krammer P, Creter G (2015) Moderner Leichtbau bedingt kreative Fügetechnologien - die Sicht eines globalen Automobilherstellers. In: 5. Fügetechnisches Gemeinschaftskolloquium 2015, Paderborn, pp. $15-20$.

21. Hörhold R, Müller M, Merklein M, Meschut G (2016) Mechanical properties of an innovative shear-clinching technology for ultrahigh-strength steel and aluminium in lightweight car body structures. Welding in the World 60:613-620. https://doi.org/10.1007/ s40194-016-0313-0

22. Zvorykina A, Sherepenko O, Jüttner S (2020) Novel projection welding technology for joining of steel-aluminum hybrid components - part 1: technology and its potential for industrial use. Welding in the World 64:317-326. https://doi.org/10.1007/ s40194-019-00833-x

23. Schmale HC, Schneider M (2019) Herausforderungen der Elektromobilität für Werkstoffe und Fügetechnik in Karosserie, Fahrwerk und Antrieb - Antworten mit Stahl. In: 9. Fügetechnisches Gemeinschaftskolloquium 2019, Braunschweig, pp. $23-33$.

24. Mogge F, von Thaden G, Riederle S (2017) Automotive metal components for car bodies and chassis https://www.rolandberger. com/en/Insights/Publications/Metal-components-for-car-bodiesand-chassis. Last accessed: 26 January 2021

25. Goldman F (2017) Widerstandspunktschweißen als Fixiertechnologie von Aluminium-Stahl-Mischverbindungen im automobilen Leichtbau. Dissertation, Paderborn University.

26. Audi AG (2018) Audi A6 C8 Avant - Karosserie mit Anbauteilen. https://www.audi-mediacenter.com/de/audi-a6-avant-41. Last accessed: 26 January 2021.

27. Beck S, Wolfarth U, Franz T (2016) Widerstandselementschweißen beim VW Passat B8 im Einsatz. https://automobilkonstruktion. industrie.de/allgemein/punktschweissen-jetzt-aluminium-mitstahl/\#slider-intro-1. Last accessed: 26 January 2021.

28. Wiese L (2018) Einstufiges Widerstandselementschweißen für den Einsatz im Karosseriebau. Dissertation, Paderborn University.

29. Fröhlich D, Janzen V (2019) New development of hole- and threadforming screws and resistance element welding for the use of highstrength steels as well as large aluminum component thicknesses without a prehole. In: Joining in Car Body Engineering, Bad Nauheim.

30. Augenthaler F, Ditz M, Gerkens M, Günter H, Schmal C, Vorderbrüggen J, Meschut G (2018) Fügetechnik: Schlüsseltechnologie für ressourceneffiziente 
Hochleistungsverbundsysteme. In: WAW Jahresbericht Jahresmagazin Werkstofftechnik 2018. Lampertheim, pp. 126 - 130.

31. Günter H, Meschut G (2018) Fügen höchstfester Stahlgüten in Leichtbaustrukturen mittels selbststanzendem Widerstandselementschweißen auf konventionellen Widerstandspunktschweißanlagen. In: 8. Fügetechnisches Gemeinschaftskolloquium 2018, Braunschweig, pp. $77-81$.

32. ArcelorMittal (2021) Steels for hot stamping - Usibor ${ }^{\circledR}$ and Ductibor®. https://automotive.arcelormittal.com/products/flat/ PHS/usibor_ductibor. Last accessed: 26 January 2021.

33. DuPont (2021) BETAMATETM 1630. https://dupont. materialdatacenter.com/products/datasheet/SI/BETAMATE\% E2\%84\%A2\%201630. Last accessed: 26 January 2021.
34. Fan DW, de Cooman BC (2012) State-of-the-knowledge on coating systems for hot stamped parts. Steel research international 83(5): 412-433. https://doi.org/10.1002/srin.201100292

35. Sherepenko O, Schreiber V, Schischin I, Wohner M, Wenlein P, Mitzschke N, Jüttner S (2020) Influence of surface layers on resistance spot joinability of partially hardened steel $22 \mathrm{MnB} 5$ with aluminum-silicon and zinc coatings. Welding in the World 64: 755-771. https://doi.org/10.1007/s40194-020-00864-9

36. Gullino A, Matteis P, D’Aiuto F (2019) Review of aluminum-tosteel welding technologies for car-body applications. Metals 2019(9):315. https://doi.org/10.3390/met9030315

Publisher's note Springer Nature remains neutral with regard to jurisdictional claims in published maps and institutional affiliations. 